\title{
The Japanese Employment System after the Bubble Burst: New Evidence*
}

\author{
Ryo Kambayashi and Takao Kato**
}

March 2009

Prepared for Japan's Bubble, Deflation and Long-term Stagnation, Federal Reserve Board San

\begin{abstract}
Taking advantage of our first access to micro data from the 2002 Employment Status Survey (ESS) as well as previous years of the ESS, we provide new evidence on changes in the "lifetime employment" practice which serves as a foundation for the Japanese employment system. Overall, we find evidence for the resilience of the Japanese employment system. Job stability of regular employees did not fall much during the first five years of Japan's Great Recession following the bubble. Our cohort analysis of narrowly-defined "lifetime employment" workers (new school graduate hires) also points to the stability of the size of the "lifetime employment" pool over time. To be consistent with the enduring nature of the "lifetime employment" system, we also find some evidence for the buoyancy of other complementary elements of the Japanese employment system. This, however, does not mean the complete rigidity of the Japanese employment system. Apparently the Japanese employment system has evolved in response to Japan's prolonged stagnation. First, job stability of regular employees eventually fell during the final years of the Great Recession. It took years yet the magnitude of the fall turned out to be notable and for some groups of workers it was large. Second, the burden of downsizing during Japan's prolonged stagnation fell disproportionately on women as opposed to men and on highschool graduates as opposed to college graduates. The largest fall in job stability was found for female regular employees who were mid-career hires and working for large firms. We interpret our findings as a largely rational response of Japanese firms that were in dire need for downward employment adjustment yet were concerned about the cost of reneging on their implicit longterm employment contracts.
\end{abstract}

*We benefitted greatly from comments from the Editorial Committee, Joe Altonji, Till von Wachter, and other participants at the ESRI Workshop on Japan's Bubble, Deflation and Longterm Stagnation, March 21 - 22, 2008, Columbia University.

**Kato is W.S. Schupf Professor of Economics and Far Eastern Studies, Colgate University; Research Fellow, IZA Bonn; and Research Associate, Center on Japanese Economy and Business (Columbia Business School), Tokyo Center for Economic Research (University of Tokyo), and Center for Corporate Performance (Aarhus School of Business). Ryo Kambayashi is Associate Professor, Institute of Economic Research, Hitotsubashi University. Kato is the corresponding author: Email; tkato@mail.colgate.edu. Address: Department of Economics (Persson 222),Colgate University, 13 Oak Drive, Hamilton, NY 13346. Phone: 315-228-7562 Fax: 315228-7033 


\section{The Japanese Employment System after the Bubble Burst: New Evidence}

\section{Introduction}

In the 1980s, the Japanese employment system became a source of wonder for many corporations around the world and a popular subject of research for scholars in industrial relations, human resource management, and labor economics. There is indeed some evidence that the aforementioned Japanese employment system helped Japanese firms enhance their productivity. ${ }^{1}$ However, during Japan’s prolonged stagnation following the bubble, the popular rhetoric shifted and became less positive about the Japanese employment system. In particular, the practice of "lifetime employment" (or implicit long-term employment guarantees for the regular workforce), which is often considered a foundation for the Japanese employment system, has been criticized as an important example of "rigidity" of the Japanese labor market and hence a structural impediment to the swift and robust recovery of the Japanese economy (Ono and Rebick, 2003). ${ }^{2}$

In addition, there is currently a lively debate among scholars and policy makers surrounding the viability of the practice of "lifetime employment" and the role of public policy in influencing such a practice. For instance, Chuma (1998) and Ono and Rebick (2003) argue a change in the legal environment in Japan following the first oil crisis in the mid-1970s made it even more difficult for Japanese employers to lay off their employees, resulting in increased (2002).

${ }^{1}$ See, for instance, Jones and Kato (1995), Ohkusa and Ohtake (1997), and Kato and Morishima

${ }^{2}$ The term "lifetime" is somewhat of a misnomer since except for executives, Japanese workers have been typically subject to mandatory retirement that occurs around age 60 . A precise definition of the practice of lifetime employment is therefore implicit long-term employment contract that ends at mandatory retirement for the regular workforce. In addition, the practice of "lifetime employment" does not necessarily mean that layoffs never happen in large Japanese firms. It has been documented that Japanese firms, even large ones, did lay off some of their regular employees, following the first oil crisis (see, for example, Koike, 2005, Suruga, 1998, Nakata, 2003, Chuma, 2002). 
rigidity of the Japanese labor market and heightened barriers to the development of effective external labor markets. Such absence of effective external labor markets allegedly fosters inefficient allocation of labor and hence lower productivity (see Ariga and Okazawa, 2007 for such labor market mismatch during the Great Recession). However, recent work on employment protection laws in Japan points to long-term stability of the legal environment surrounding employment protection in Japan at least up until 1997 (see, for instance, Kambayashi and Kawaguchi, 2008). Furthermore, theorists stressing the positive incentive effects of job security in formation of firm-specific human capital and knowledge and the importance of institutional complementarity predict the resilience of "lifetime employment" as an equilibrium (Aoki, 2000 and Moriguchi and Ono, 2004).

In spite of such a lively debate, we are struck by the surprising paucity of rigorous and useful evidence on changes in the practice of "lifetime employment" or lack thereof during Japan’s long-term stagnation. ${ }^{3}$ Specifically we desperately need reliable evidence on: (i) whether the "lifetime employment" system evolved in response to real adverse shocks following the bubble burst and if so: (ii) in what way and (iii) how quickly. Only after obtaining satisfactory answers to such key questions, we can begin to understand the precise role that the employment system played in Japan's prolonged stagnation. ${ }^{4}$

This paper fills this important gap in the literature by providing much-needed rigorous evidence on changes in the practice of "lifetime employment" after the bubble burst (or lack thereof). Overall, we find evidence for the resilience of the Japanese employment system. Job stability of regular employees did not fall much during the first five years of Japan’s Great Recession following the bubble. Our cohort analysis of narrowly-defined "lifetime employment"

\footnotetext{
${ }^{3}$ We are not the first to recognize an urgent need for such evidence (Dore, 1996)

${ }^{4}$ A few earlier attempts include Genda and Rebick (2000), Kato (2001, 2003), and Ono and Rebick (2003).
} 
workers (new school graduate hires) also points to the stability of the size of the "lifetime employment” pool over time. This, however, does not mean the complete rigidity of the Japanese employment system. First, job stability of regular employees eventually fell during the final years of the Great Recession. It took years yet the magnitude of the fall turned out to be notable and for some groups of workers it was large. Second, the burden of downsizing during Japan's prolonged stagnation fell disproportionately on women as opposed to men and on high-school graduates as opposed to college graduates. The largest fall in job stability was found for female regular employees who were mid-career hires and working for large firms. We interpret the findings as a rational response of Japanese firms that were in dire need for downward employment adjustment yet were concerned about the cost of reneging on their implicit longterm employment contracts.

In the next section, we set out our empirical strategy while reviewing prior studies briefly. The subsequent four sections present our key findings, followed by the concluding section in which we highlight and interpret our key findings.

\section{Prior Studies and Data}

Ono (2007) provides a comprehensive and up-to-date review of the literature and concludes that the existing evidence on changes in the "lifetime employment" system during Japan's prolonged stagnation is mixed and that different groups of workers (such as women vs. men; young vs. old; high tenure vs. low tenure; large vs. small firms) tend to be exposed to different kinds of changes, pointing to the importance of disaggregated analysis. In this section, instead of repeating a full literature review, we demonstrate that data limitations (especially the lack of access to up-to-date micro data from the Employment Status Survey) have been a major 
culprit for prior studies' inability to provide conclusive evidence, and that our paper overcomes the data challenge and produces much needed reliable and updated evidence on changes in Japan’s “lifetime employment” system during Japan’s prolonged stagnation.

Hashimoto and Rasian (1985) provide the first rigorous evidence on the practice of “lifetime employment” during Japan’s high growth period (1962-77) by applying the procedures developed by Hall (1982) to aggregate data from the Employment Status Survey (the Japanese counterpart of CPS tenure supplements of the U.S.). ${ }^{5}$ To study the possible transformation of Japan’s “lifetime employment” system, Kato (2001) used published and unpublished tables from various years of the Employment Status Survey (ESS) ${ }^{6}$ and estimated the ten-year job retention rates of Japanese employees (probability of a Japanese employee to work for the same employer for the next ten years) for the two time periods (ten years before and after the bubble burst. Kato (2001) finds no evidence that the ten-year job retention rates of Japanese employees fell from the period prior to the bubble burst to the post-bubble stagnation period.

As Kato (2001) acknowledges, however, the latest data available to calculate the job retention rates at the time of his research were from the 1997 ESS, and Japan's stagnation turned out to have continued for five more years. It is quite plausible that those additional five years of stagnation might have finally caused Japanese firms to start weakening the practice of "lifetime employment."

Considering the final years of the Great Recession is particularly important for two

\footnotetext{
${ }^{5}$ Interest in studies of the importance of long-term employment in the U.S. was rekindled in late 1990s in light of the rising popular perception of disappearing long-term jobs in the U.S. In response, a number of researchers in the U.S. have been using CPS tenure supplements to address this popular perception (see, for example, Farber, 1998, and Neumark, et. al., 2000).

${ }^{6}$ There is, however, an alternative dataset available for Japan, i.e., the Basic Survey of Wage Structure (often called the Wage Census data). Though the Wage Census data are obtained from an establishment-level survey and hence not comparable to CPS tenure supplements, they provide information necessary to calculate job retention rates. The use of this alternative data source turned out to produce similar results, i.e., no evidence for the weakening lifetime employment (Chuma, 1998).
} 
reasons. First, prior to its 1998 revision, Japan’s Labor Standards Law prohibited Japanese firms from offering multi-year fixed-term contracts. As a result, Japanese firms were in essence forced to choose between indefinite contracts (or open-ended contracts) and fixed-term contracts of one year or less when contemplating to offer jobs to prospective employees. As such, Japan's Labor Standards Law may have given Japanese firms incentives to hire more workers under indefinite contracts. The 1998 revision relaxed the prohibition of multi-year contracts, and hence made it easier for Japanese firms to hire fixed-term contract workers. Apparently the relaxation of the Labor Standards Law with regard to multi-year fixed contracts was consequential. For example, according to the Yuki-Keiyaku-Rodo ni Kansuru Jittai-Chosa (Survey on Fixed-term Labor Contracts) conducted by the Japanese government in 2005, nearly one in four fixed-term contract workers were under multi-year contracts. Since being on indefinite contracts is often a prerequisite for "lifetime employment”, the 1998 revision of the Labor Standards Law is potentially a cause for the weakening of the "lifetime employment" system (Ono and Rebick, 2003).

Second, recent macroeconomic studies of employment adjustment in Japan tend to suggest that the speed of adjustment of labor input to output at the macro level rose as Japan’s stagnation continued (Higuchi, 2001 and Miyanaga, 2002). ${ }^{7}$

The unavailability of data covering the final years of the Great Recession is not the only data limitation that plagued prior studies. The practice of "lifetime employment” was never applied equally to all employees in Japan. ${ }^{8}$ Therefore, more serious data limitation of prior empirical studies of Japan's "lifetime employment” is the lack of access to individual worker-

\footnotetext{
${ }^{7}$ We are, however, aware that microeconomic studies of employment adjustment using firm-level micro data often fail to find such evidence (Kambayashi and Kawaguchi, 2008). This paper is the first to address this issue, using individual worker-level micro data.

${ }^{8}$ Ono (2007) summarizes differing views on the scope of "lifetime employment" (Table 1).
} 
level micro dataset which provides information on tenure (number of years with the firm). Indeed, Moriguchi and Ono (2004) argue that the scope of "lifetime employment” has been evolving over time and speculate that the significant expansion of the scope of "lifetime employment” occurred during the bubble period in large part as a response to the economy-wide severe labor shortage. ${ }^{9}$ It is perfectly plausible that the scope of the "lifetime employment" practice might have been receded during Japan’s prolonged stagnation and that implicit "lifetime employment” contracts were withdrawn from the segment of the Japanese labor force that were added to the pool of "lifetime employees" during the bubble period. As such, the lifetime employment system may prove to be resilient, maintaining the core segment while not covering other segments of the Japanese labor force (e.g., female regular workers, regular employees who were hired in mid-career). Publicly available aggregate data from the ESS do not allow for detailed disaggregate analysis necessary for addressing such important questions.

We were extremely fortunate to be able to persuade the Japanese government to grant us full access to individual-level micro data from the Employment Status Survey (ESS) for 2002, 1997, 1992, and 1987. ${ }^{10}$ The ESS provides rich information on individual employees (not only job tenure but also various other individual characteristics including gender, age, education, employment status (regular vs. non-regular), and firm size. In short, we take advantage of our first access to micro data from the ESS including the most recent 2002 data and overcome the aforementioned two key data challenges of prior studies. practice.

${ }^{9}$ Chuma (1998) provides evidence for such an expansion of the scope of the lifetime employment

${ }^{10}$ Though we are the first to use the 2002 ESS to study job retention, aggregate data from the 2002 ESS data are being analyzed by several researchers. For instance, a recent working paper by Farber (2007) uses the 2002 ESS as well as the ESS from previous years and CPS Tenure Supplements and conducts an intriguing cross-national comparison of the evolution of long-term employment between Japan and the U.S. with particular focus on the role of unique institutions in labor adjustments to globalization in recent years. 


\section{Changes in Ten-year Job Retention Rates before and after the Bubble Burst}

Follow the standard job retention formula used by prior studies (Hall, 1982, Hashimoto and Raisian, 1985, and Kato, 2001), we calculate the ten-year job retention rates of all regular employees for the three time periods, 1982-1992, 1987-1997 and 1992-2002. Specifically,

1. we first use the base year ESS (1982, 1987, and 1992) and calculate the proportion of civilian noninstitutional population who are regular employees in each age-tenure category, say ages 25-29 with 0-4 years of tenure (or the total number of regular employees ages 25-29 with 0-4 years of tenure, divided by the civilian noninstitutional population in the corresponding age category or ages 25-29);

2. we then use the ESS ten years later (1992, 1997, and 2002) and calculate the proportion of civilian noninstitutional population who are regular employees in ages 35-39 with 1014 years of tenure (or the total number of regular employees ages 35-39 with 10-14 years of tenure, divided by the civilian noninstitutional population in the corresponding age category or ages 35-39); and

3. we finally divide the proportion regular employees ages $25-29$ with $0-4$ years of tenure as obtained in the first step by the proportion regular employees ages 35-39 with 10-14 years of tenure as derived in the second step.

The resulting ratio is the ten-year job retention rate of regular employees ages 25-29 with 0-4 years of tenure. ${ }^{11}$ We focus on regular employees as opposed to non-standard employment workers (such as fixed-term contract workers, subcontract temporary workers, part-timers and

\footnotetext{
${ }^{11}$ Using the number of employees in each age-tenure category itself instead of using its ratio to the relevant civilian noninstitutional population will change the ten-year job retention rates very little, as expected for Japan since immigration and incarceration are far less important in Japan than in other major industrialized economies, such as the U.S. and Germany.
} 
other contingent workers) in our study of changing "lifetime employment", for the literature almost unanimously considers non-standard employment workers outside of the "lifetime employment” system (see, for instance, Koike, 1977 and Ono, 2007). ${ }^{12}$

As shown in Table 1, the ten-year job retention rates of regular employees fell significantly from the 1982-92 period to the 1992-2002 period for all age-tenure categories with one exception (the entry-level age category for high-school graduates, or age15-19 with 0-4 years of tenure), and the magnitude of the fall was considerable for some categories. For instance, the average regular employee age 35-39 with 0-4 years of tenure in 1982 had a 63 percent chance of being with the same employer ten years later (1992) whereas the average employee in the same age-tenure category in 1992 had only a 49 percent chance of being with the same employer ten years later (2002).

To discern whether the fall in job retention rates occurred only during the final years of Japan’s prolonged stagnation, we also calculated the job retention rates for the 1987-1997 Period. As shown in Table 1 (in particular the last three columns which show changes in the retention rates from one period to another), we find no evidence for significant changes in job retention rates from the 1982-92 period to the $1987-97$ period, which is consistent with Kato (2001). Most changes appeared to have occurred during the last five years of the Great Recession, suggesting that "lifetime employment" might have started to weaken, at last during the latter half of the Great Recession.

However, Table 1 also shows that the fall in job retention rates during the last five years of the Great Recession is hardly uniform across age-tenure categories, suggesting the possibility that "lifetime employment" weakened mostly among certain subsets of the Japanese labor force.

\footnotetext{
${ }^{12}$ Regular employees are supposed to be on indefinite contracts as opposed to fixed-term contracts. Reassuringly we are able to confirm from the ESS that nearly all regular employees are indeed on indefinite contracts.
} 
To explore such a possibility further, we repeat the same analysis for men and women separately. Likewise, we study college graduates and non-college graduates as well as employees of firms with different firm sizes separately.

Tables 2A and 2B present ten-year job retention rates calculated separately for male and female regular employees. Overall, women appeared to have experienced more substantial reductions in job stability during Japan's Great Recession than men. In particular, women age over 30 with relatively short tenure used to enjoy ten-year job retention rates of 60 percent or higher prior to the Great Recession. During the Great Recession, however, their ten-year job retention rates fell considerably by about 20 percentage points.

Those female regular employees over age 30 with $0-4$ years of tenure represent "Chuto Saiyou (mid-career hires)" as opposed to traditional "Shinsotsu Saiyou (new graduate hires)”. They are hardly a negligible and disappearing segment of the Japanese labor force. As shown in the same table, such female regular employees who are mid-career hires constituted a little less than 7 percent of the relevant age cohort prior to 1992. The share of female regular employees who are mid-career hires rose to 8.8 percent by 1992 .

Figure 1 shows changes in gender gap in job stability (=difference in ten-year job retention rates between male and female regular employees) during Japan’s prolonged stagnation. The Figure demonstrates vividly a striking reversal of fortune for female regular employees who are mid-career hires. Until 997, female regular employees who were mid-career hires actually enjoyed higher ten-year job retention rates than their male counterparts (by up to 15 percentage points). Note that we are comparing a specific group of workers, or regular (as opposed to nonstandard) employees who are mid-career hires between women and men. ${ }^{13}$ During the final five

\footnotetext{
${ }^{13}$ When we consider all employees include not only regular employees but also non-standard employment workers, such as fixed contract workers, subcontract temporary workers, and part timers,
} 
years of the Great Recession, however, such advantages disappeared and for regular employees age 30-34 with 0-4 years of tenure, the fortune was completely reversed with women now facing a much lower ten-year job retention rate than men.

The literature suggests that college graduates are more likely to enjoy "lifetime employment” than high school graduates (see for instance Tachibanaki, 1984 and Ono, 2007). We repeat the same analysis for college graduates and high school graduates separately. Tables 3A and 3B report ten-year job retention rates of male regular employees with and without college degrees. Figure 2 shows the differences in ten-year job retention rates between college graduates and high school graduates for the three time periods. As confirmed by the tables and demonstrated vividly by Figure 2, ten-year job retention rates were overall higher for college graduates than for high school graduates, as prior studies suggest. Perhaps more importantly, the gap in job stability by educational level appeared to have widened during the Great Recession. The only exception was male regular, college-educated employees age 20-24 with 0-4 years of tenure (entry level for new college graduates) who experienced a substantial reduction in job stability during the last five years of the Great Recession. Except for this entry level, the erosion of "lifetime employment" during the Great Recession was greater for high school graduates than for college graduates. Tables 4A and 4B repeat the same analysis for female regular employees. In essence, we observe a similar widening of education gap in job stability between college graduates and high-school graduates for female regular employees as well.

Finally, we study changes in job retention rates of regular employees of firms with varying size. The literature often argues that the "lifetime employment" practice applies mostly

even before 1997, ten-year job retention rates of female employees were actually lower than male employees. As such, the lack or even reverse of gender gap in job stability was specific to regular employees who are mid-career hires. 
to workers in large firms (typically those with 500 or more employees), and that workers in small to medium firms were traditionally excluded from the "lifetime employment" system (see for example Koike, 2005, and Ono, 2007). We calculated ten-year job retention rates of male and female regular employees working in firms with three different sizes (large with 500 and more employees; medium with 30-499 employees; and small with fewer than 30 employees).

For male regular employees in large firms, as shown in Table 5A, job retention rates of their older high tenure workers, such as age 30-44 with 5 or more years of tenure fell far less than those of their young ones, in particular age 20-24 (3 to 7 percentage points vs. 17 percentage points). Large firms appear to have been holding on to their older high tenure workers but not their younger ones. ${ }^{14}$ Such contrasting changes in job security between old high tenure workers and young workers are, however, not apparent for small to medium size firms (Tables 5B and 5C). Unlike in those in large firms, old high tenure workers in small and medium size firms appear to have experienced greater reductions in job security than their younger counterparts. It follows that during the final years of the Great Recession the gap in job security between large and small firms rose for old high tenure workers while diminishing for young workers, as demonstrated by Figure 3A.

Earlier, we discovered that the burden of downsizing during the Great Recession appeared to have fallen disproportionately on female regular employees over age 30 with less than 5 years of tenure (or mid-career hires as opposed to traditional new graduate hires). For female regular employees, most notable changes in job security gaps between large and small firms are found for such mid-career hires. Specifically, on one hand, Table 6A confirms a similarly large reduction in job stability for such female regular employees who are mid-career

\footnotetext{
${ }^{14}$ For the issue of youth employment problem in Japan during the Great Recession, see for example, Genda (2003)
} 
hires in large firms during the last five years of the Great Recession whereas other female regular employees with relatively longer tenure experienced much less severe deterioration of their job security. On the other hand, Tables 6B and 6C reveal that no such sharply asymmetric reductions of job retention rates between female regular employees with short and long tenure exist for small and medium firms. It follows that for female regular employees who are mid-career hires, the traditional divide in job security between large and small firms diminished considerably during the last five years of the Great Recession. Indeed, as shown in Figure 3B, for female regular employees ages 35-39 and 40-44 with less than 5 years of tenure (typical mid-career hires), the fortune was actually reserved during the last five years of the Great Recession, or their jobs became LESS secure in LARGE firms than in SMALL firms.

Finally, to provide some benchmark for what we have reported thus far, we use CPS Tenure Supplements to calculate the most recent ten-year job retention rates of U.S. employees. Notwithstanding the definitional and methodological differences between the ESS and the CPS (e.g., it is impossible to apply the Japanese definition of "regular employees" strictly to the U.S. data), we believe that the ten-year job retention rates of U.S. male employees for core age-tenure categories (such as ages 30-34, 35-39, and 40-44 with 5 or more years of tenure) can be a useful benchmark. When the ten-year job retention rates of Japanese regular male employees for such core age-tenure categories fall to the levels of U.S. male employees for the same age-tenure categories, we can probably safely declare the end of the Japanese "lifetime employment" system. To this end, our estimates on the ten-year job retention rates of U.S. male employees over the time period of 1996-2006 are 47.24; 54.65; and 59.45 percent for age 30-34 with tenure 5+; age 35-39 with tenure 5+; and age 40-44 with tenure 5+. The corresponding Japanese figures over the time period of 1992-2002 are 70.21; 75.00; and 72.10 which are still considerably higher than 
the U.S. levels.

\section{Cohort Analysis of New Graduate Hires}

In the previous section we provide evidence on changes in job stability after the bubble burst (in particular during the last five years of the Great Recession) for a group of Japanese workers, regular employees. As discussed before, to be hired as a regular employee is often a necessary condition for "lifetime employment" although it is not a sufficient one. The literature on "lifetime employment" sometimes add explicitly the second condition, employment immediately following school graduation (Ono, 2007). In this section, we focus on such a narrowly-defined pool of “lifetime employment” workers who were employed as regular employees right after school graduation, and hence satisfy the above two conditions for "lifetime employment.” Two specific groups of employees can be identified in the ESS as those constituting the pool of narrowly-defined "lifetime employment” workers: (i) new college graduate hires (regular employees age 20-24 with tenure 0-4); and (ii) new high-school graduate hires (regular employees age 15-19 with tenure 0-4).

The main objective of this section is to discern any changes in the size of the narrowlydefined “lifetime employment” pool over time (especially during Japan’s prolonged stagnation), and hence provide some evidence on the decline in the overall prevalence of the "lifetime employment” practice in the Japanese economy. Unfortunately, there is no well-established methodology to measure the overall prevalence of the "lifetime employment" practice in the economy (see Ono, 2007 for more on such methodological challenges). To this end, we devised our own cohort analysis method (Figures 4-17 summarize the results from the cohort analysis) which we hope will be instrumental in the development of a more general and complete 
approach in the future.

As shown in Figures 4 and 6, the ESS for 1982, 1987, 1992, 1997, and 2002 provide data on seven cohorts of new college graduate hires for male and female college graduates: Cohort $\mathrm{X}$ (those college graduates who were 20-24 years old with 0-4 tenure in Year X for X=1967, 1972, 1977, 1982, 1987, 1992, and 1997.) For example, Cohort 1967 shows up in our first ESS (1982) as regular college graduate employees age 35-39 with tenure 15-19. From the second ESS (1987) we can discern how many of Cohort 1967 remained in the same firm for five more years by counting the number of regular college graduate employees age 40-44 with 20-24 years of tenure. Likewise, the 1992 ESS allows us to estimate how many of Cohort 1967 remained in the “lifetime employment” pool for the next five years. To highlight the importance of such evolving “lifetime employment” pool over time, we express the "lifetime employment” cohort size as a percentage of total employment (including both regular and non-standard employment) in the corresponding age cohort. We repeat the same analysis for the remaining six cohorts.

As shown in Figure 4, the 1987 cohort of male new college graduate hires constituted 23 percent of total employment in the corresponding age cohort in 1987 when they were hired as regular employees upon college graduation. Since the 1987 was among the final years of Japan's Bubble Period, we can consider the 1987 cohort the last cohort before the Bubble Burst. As the job retention rate estimates for male college-educated regular employees suggest, not all new college graduate hires remained in the "lifetime employment” pool as they age. Thus, in 1992 (five years later), the 1987 cohort who remained in the same firm fell to 16 percent (30 percent drop from the 1987 level). ${ }^{15}$ In 1997 (ten years later), the surviving 1987 cohort constituted a little over 13 percent. By 1997 (fifteen years later), the 1987 cohort who was still in the

\footnotetext{
${ }^{15}$ For the relatively high turnover of new graduate hires in their first five to ten years in Japan, see for instance Koike (2005).
} 
narrowly-defined "lifetime employment" pool was down to 9 percent of all workers in the cohort.

Before comparing the 1987 cohort to the post-bubble cohorts, let us note that the time profiles of all cohorts prior to the 1987 cohort were also downward-sloping and roughly in parallel to the time profile of the 1987 cohort while the figure shows a steady upward shifting of the time profiles from the 1967 cohort to the 1977 cohort, suggesting the strengthening of the "lifetime employment” system during the high growth era.

The 1992 cohort began at a higher level (26 percent as opposed to 23 percent for earlier cohorts) when they were hired as regular employees upon college graduation in 1992. The size of the 1992 cohort remaining in the same firm dropped by about 30 percent in the next five years, which is comparable to the drop in the size of the 1987 cohort for the first five years. However, the next five years (1997-2002) proven to be a trying time for them with the size of the surviving cohort falling at a faster rate than at the historical rate, ending up being close to the historical level for most prior male new college graduate hires at the same stage of their careers (age 30-34 with 10-14 years of tenure). In other words, in 1992, the initial size of the "lifetime employment" cohort for college graduates was significantly larger than in prior years. However, in the following ten years, in particular the last five years (1997-2002), the initially inflated size of the "lifetime employment" pool was quickly adjusted to return to its historical level.

The 1997 cohort (those hired as regular employees immediately following college graduation in the midst of the Great Recession) also started at a level higher than the historical level (actually even higher than the 1992 cohort).Again, in the next five years (1997-2002), the initially inflated size of the "lifetime employment" pool was quickly adjusted downward (amounting to a 46-percent drop in its size) to return to the same level as those cohorts prior to the Bubble Burst. 
In short, overall, the male cohorts of new college graduate hires (those hired as regular employees immediately following college graduation) show relative stability over time in terms of their sizes and time profiles whereas the 1992 and 1997 cohorts experienced an unusually sharp drop in its size for their first five to ten years, suggesting more vigorous and selective onthe-job screening of new college graduate hires in early years of their careers during the Great Recession. The finding is largely consistent with our earlier analysis of the ten-year job retention rate documenting the significant drop in the ten-year job retention rates for male regular employees with college degrees during the Great Recession (Table 3A).

Figure 5 shows the results from a similar cohort analysis of the new high-school graduate hires for male. The time profiles of all cohorts are downward-sloping with the very large drop for the first five years, which is mostly due to a sharp increase in total employment in the cohort at age 20-24 as a result of inflow of college graduates into the labor market. The figure shows a downward shift of the time profiles of the new high school graduate hires over time, which is consistent with Ariga (2005) who documents the deteriorating job market for high school graduates over time in Japan.

Figures 6 and 7 repeat the same analysis for female regular employees. The results are by and large similar to those for male regular employees with one important exception that the relative cohort size of new graduate hires remaining in the same firm falls more precipitously for their first five to ten years than their male counterparts. ${ }^{16}$ For example, the 1987 cohort of female new college graduate hires constituted 35 percent of total female employment in the cohort in 1987, a much higher level than the male counterpart (23 percent). However, the size of the

${ }^{16}$ Such sharp drops are consistent with prior studies reporting a significant break in career for women due to marriage and childrearing (see, for example, Rebick, 2005). 
narrowly-defined "lifetime employment” pool of female new college graduate hires dropped more rapidly than the male counterpart as they age for the first five to ten years and ultimately reached the same level as the male counterpart. Thus, in 1992 (five years later), the 1987 cohort of female new college graduate hires who were still with the original firms dropped to 21 percent (67 percent drop from the 1987 level). In 1997 (ten years later), the surviving 1987 cohort constituted 15 percent. By 1997 (fifteen years later), the surviving 1987 cohort was down to 9 percent of all workers in the cohort, which is the same level as the 1987 cohort of male new college graduate hires reached in 1997.

As in the case of male regular employees, the 1992 and 1997 cohorts of new college graduate hires for female regular employees did start with higher levels than their predecessors and then fell sharply toward the historical levels (Figure 6).

Figure 7 shows that the time profiles of all cohorts of new high-school graduate hires are downward-sloping with the very large drop for the first five years, as in the case of their male counterparts. However, again the drop in the size of the "lifetime employment" pool for the first five to ten years was sharper than the male counterparts. ${ }^{17}$

\section{$\underline{\text { 5. Non-standard Employment }}$}

The rising share of non-standard employment (such as fixed-term contract workers, subcontract temporary workers, part-timers and other contingent workers) in Japan in recent

${ }^{17}$ As Edwards and Pasquale (2003) point out, the proportion of young women in Japan going beyond high schools and enrolling in four-year universities has been rising remarkably since mid-1980s. The observed sharper fall in the size of the female high-school graduate cohort as a percentage of total employment in the cohort for the first five years is consistent with this supply-side change (the rising size of inflow of college graduates into the labor market makes the rapid growth of the denominator for the first five years even more pronounced) 
years has been reported as evidence for the declining influence of the "lifetime employment" practice in Japan (Rebick, 2005, and Ono, 2007). Our ESS data also confirm the increasing share of non-standard employment in Japan as shown in Figure 8. More importantly we show that the rising share of non-standard employment is particularly pronounced among women, and that the significant increase in the share of non-standard employment among women began well before the bubble burst, and hence Japan's prolonged stagnation following the bubble burst would not be the underlying cause for the rising share of non-standard employment. However, the share of non-standard employment for men did begin to rise noticeably in 1997. This finding suggests that the prolonged stagnation might have finally prompted Japanese firms to extend the use of non-standard employment to men.

Figures 9 and 10 are created to uncover any possible interplay between the share of nonstandard employment and education/firm size. Figure 9 reveals that for women non-standard employment is more prevalent among high-school graduates than among college graduates. However, there is no such difference by education level for men except for the last five years of the Great Recession during which the share of non-standard employment rose more rapidly for high-school graduates than for college graduates.

Figure 10 presents intriguing interplay between gender and firm size in shaping up the share of non-standard employment. Specifically, for both men and women, there has been a negative correlation between firm size and the share of non-standard employment. However, for women, the size differential in the share of non-standard employment has been diminishing most rapidly during the Great Recession as large firms have been quickly catching up with small and medium firms in terms of the use of non-standard employment. For men, nonetheless, there is no such narrowing of gap by firm size in the share of non-standard employment. 


\section{Changes in Other Elements of the Japanese Employment System}

This section provides relatively brief discussions on changes (or lack thereof) in some of the other important elements of the Japanese employment system during the Great Recession. ${ }^{18}$ We believe such discussions are necessary in order to better understand the evolution of the "lifetime employment" system, for the "lifetime employment" system is believed to be strongly complementary to all other elements of the Japanese employment system. ${ }^{19}$

First, the seniority wage system (in which wage is not attached to specific jobs and seniority plays a significant role in wage determination) provides workers with incentive to stay in the firm and hence is complementary to the "lifetime employment" practice. Using published tables from the General Survey on Working Conditions (Former "the General Survey on Wages and Working Hours System") conducted in 1996, 1999, 2004 and 2007 by the Ministry of Health, Labor and Welfare, we created Table 7. The sample universe of the Survey is all firms in Japan that employ 30 or more employees and the Survey enjoys an unusually high response rate of close to 80 percent in 2007.

First, the proportion of firms which abolished automatic annual pay raise during the last three years was less than 4 percent in 1996 and it rose to over 10 percent in 1999; and it fell somewhat to 7 percent in 2007 although it is still considerably higher than the 1996 level. The tendency to move away from seniority-based pay by abolishing automatic annual pay raise accelerated in late 1990s and in 2007 the proportion of such firms is still higher than at the 1996 level.

\footnotetext{
${ }^{18}$ For the other important elements of the Japanese employment system, see, for example, Koike, 2005, Aoki, 2000, Itoh, 1994, Morita, 2001; 2005, Moriguchi and Ono, 2004 and Rebick, 2005.

${ }^{19}$ For the importance of job security in the participatory employment system such as the Japanese system, see for example Levine (1995) and Carmichael and MacLeod (1993).
} 
In parallel to the tendency to abolish automatic annual pay raise, a growing number of firms have been making their pay systems more sensitive to each worker’s ability; performance; and job. Specifically, the proportion of firms that made their pay systems more reflective of each worker's job and task during the previous three years rose from 12 percent in 1996 to 23 percent in 2007. Likewise, the proportion of firms that made their pay systems more sensitive to each worker's ability during the previous three years increased from 16 percent in 1996 to 22 percent in 2007. Finally, the proportion of firms that moved further toward pay for performance also rose from 15 percent in 2003 to 24 percent in 2007.

In short, we have some evidence suggesting that Japanese firms have been deemphasizing the importance of seniority and stressing the importance of merit and performance in their wage policies. ${ }^{20}$

Second, extensive information sharing mechanism (often called Joint Labor-Management Committees, JLMCs), which is designed to minimize information asymmetry and facilitate the alignment of interest between labor and management, is often considered a key element of the Japanese employment system. ${ }^{21}$

Figure 11 was created, using published tables from the Labor-Management Communication Survey (LMCS) in 1989, 1994, 1999, and 2004. The LMCS has been conducted by the Ministry of Health, Labor and Welfare every five years and the most recent Survey was conducted in 2004. The sample universe of the LMCS is establishments of firms with more than 30 workers (50 workers prior to the 1999 LMCS). The LMCS has been enjoying an unusually high response rate (around 70 percent).

\footnotetext{
${ }^{20}$ Tsuru, Abe and Kubo (2005) conduct an excellent "insider econometric study" of pay system changes in Japan.

${ }^{21}$ For Japanese JLMCs and other participatory practices, see Kato (2003) for example.
} 
Since the sample universe expanded in 1999 and started including establishments of smaller firms, we report all of the results disaggregated by firm size. As shown in Figure 11, for establishments of large firms with 5,000 or more employees, the incidence of JLMCs (percent establishments with JLMCs) has continued to increase from 1989 to 2004. For establishments of firms with 1,000-4,999 employees, the incidence remained around 65 percent during Japan's prolonged stagnation.

Figure 11, however, reveals the falling incidence of JLMCs among establishments of smaller firms. For instance, for establishments of medium-size firms with 300-999, 67 percent of establishments had standing JLMCs at the beginning of Japan's long stagnation and by the end of her great recession, only 43 percent of establishments had JLMCs.

In short, we find evidence pointing to a deeper divide between workers in large firms and the rest of the labor force. Employees working for larger firms in Japan are more likely to be provided with JLMCs than those working for smaller firms. This participation gap appears to have widened during Japan's prolonged stagnation. ${ }^{22}$ Though not reported here, we also found similar evidence for SFCs (Shopfloor Committees), which is an important example of employee involvement and problem solving activities at the grass roots level aimed at providing workers with opportunities to exert discretionary effort, acquire useful local knowledge, and share it with their co-workers, and higher-level engineers and managers.

\footnotetext{
${ }^{22}$ It is beyond the scope of this paper to pin down precisely what has been causing the deepening divide of the Japanese labor market during the Great Recession. Unfortunately, in the absence of panel data on the use of JLMCs by Japanese firms, it is at the moment impossible to know to what extent the declining incidence of such an institution among establishments of small to medium size firms has been caused by the dismantling of existing JLMCs or by exiting of firms with JLMCs and entries of new firms without JLMCs. We suspect that the dismantling of JLMCs will be more difficult in unionized firms due to their resistance and that the termination of JLMCs would be easier in small to medium size firms that are mostly without union. It is assuring that the incidence of JLMCs, as shown in Figure 1, has remained quite high at around 80 percent for establishments of unionized firms.
} 
A key financial incentive mechanism to promote the Japanese employment system has been ESOPs (Employee Stock Ownership Plans) used by the large majority of Japanese firms. Japanese ESOPs are perhaps best understood by comparing their main features with the better known U.S. ESOPs. Unlike U.S. ESOPs, Japanese corporations establishing an ESOP (called mochikabukai) do not receive any tax incentive to do so. To induce individual employees to participate in the ESOP, Japanese companies offer subsidies (typically with the firm matching each employee's contribution by giving 5 to $10 \%$ of the contribution as well as bearing administrative costs). While ESOPs elsewhere frequently are structured so as to encourage strong participation by top management, in Japan, executives, as well as part time and temporary employees, are normally ineligible for membership. As is the norm elsewhere, individual participants' shares and dividends in the ESOP are held in a trust. Unusually, however, each participant has the right to withdraw his or her shares, and withdrawn shares are privately owned. Withdrawals are only permitted in 1,000 share, round lots. While members may freely exit completely from the ESOP, re-entry is restricted. Exiting employees will receive their shares in 1,000 share increments, and must sell the remaining shares to the trust at the prevailing market price. Upon retirement, model rules adopted by most ESOPs require retiring workers to exit completely from the ESOP. In principle, Japanese ESOPs can function as a group incentive pay which aligns the interest between the firm and workers and prior studies find some econometric evidence for the positive productive effects of ESOPs when their free-rider problem is eased (see, for instance, Jones and Kato, 1995 and Kato and Morishima, 2002).

Since 1989, the Tokyo Stock Exchange (TSE) has been collecting data from all firms listed in TSE on their use of ESOPs. All TSE-listed firms (over 2,000 firms as of 2006) including almost all major corporations in Japan, have been supplying such data to the TSE 
every year. As such, the TSE data provide the most accurate and reliable picture of the use of ESOPs by TSE-listed firms in Japan. Most importantly, to the best of our knowledge, this is the only source of data on Japanese ESOPs available for recent years.

Using the TSE data from 1989 through 2006, the most recent year available, we produced Figure 12. The figure confirms the rapid asset price deflation following the violent burst of the financial bubble in the late 1980s and the subsequent prolonged recession that lasted until 2003. Thus, the real market value of outstanding shares owned by ESOPs, and the real value of the average stake fell sharply in the early 1990s, and recovery from this sharp drop was at best anemic till 2003.

A natural question concerning the responses of ESOPs to this seemingly powerful adverse financial shock is whether or not it discouraged employees from participating in ESOPs. The figure shows a surprisingly calm response by the labor force in firms with ESOPs to the burst of the financial bubble in the late 1980s and the subsequent long stagnation. Thus, the ESOP participation rate has been remarkably stable.

Consistent with the relatively calm response of employees, very few employers terminated their ESOPs in response to the adverse financial shock. Thus, as shown in Figure 12, the proportion of firms with ESOPs did not decline during Japan's Great Recession. Overall, it appears that neither employees nor employers have panicked in the face of the negative financial shock and the subsequent long recession. It appears as if such a calm response is paying off at last. For instance, in 2005 the average stake of ESOP participants finally recovered to the level of 1989, exceeding two million yen. In 2006, the average stake fell slightly yet still exceeded two million yen.

In short, neither hasty exit of employees from ESOPs nor the dismantling of ESOPs by 
employers took place during Japan’s Great Recession. It is, however, still possible that a more subtle fine-tuning of the existing ESOP institutions might have occurred. To see if this is indeed the case, we were fortunate that a large Japanese firm (JFIRM) continued to provide us with detailed internal data on their ESOP operation. ${ }^{23}$ JFIRM is a well-known manufacturing firm with sales of a few trillion yen, about one third of which is export sales, and employment of close to 40,000 workers. It is listed in the first section of Tokyo Stock Exchange.

JFIRM introduced its ESOP in 1971. The original objective of the ESOP was threefold: (i) enhancing the sense of participation and motivating employees; (ii) providing a source of retirement income; and (iii) acquiring a stable shareholder group. By the end of 1980, the ESOP participation rate reached one in four employees and their average monthly contribution reached 13,000 in 1995 yen. According to the Human Resources manager, there have been very few frenzied voluntary exits of employees from the trust and the ESOP is proving to be a stable shareholder.

However, there were a few subtle changes in the commitment of employees to the ESOP. First, as shown in Figure 13, in 1990, more than 1,000 continuing participants increased their monthly contributions whereas only 100 continuing participants reduced their monthly contributions. The ratio of the former to the latter number, called the "Commitment Ratio" was over 1000\%. During Japan’s Great Recession, the number of ESOP participants who increased their monthly contributions has continued to decline, except for a brief recovery of 1996, and in 2000 reached all-time low of a little over 100. There was no sign of turn-around in 2001.

In contrast, the number of ESOP participants who decreased their monthly contributions

${ }^{23}$ Since we reported our earlier case study of this firm (Kato, 2003), JFIRM has continued to invite us to conduct field research at the firm and provide us with further data. As a result, we have been able to extend our database on JFIRM beyond 1998 to include the final years of Japan's Great Recession, 1998-2001. 
grew in the early 1990s and has been fluctuating rather mildly ever since. Most importantly there is no comparable downward trend in the number of ESOP participants decreasing their

contributions. As a result, the Commitment Ratio continued to fall, except for the brief recovery of 1996-1997, and in 2000 reached all time low of almost 70\%. In other words, at the beginning of Japan's Great Recession, there were ten times more employees increasing their monthly contributions to the ESOP than decreasing their contributions. After ten years of prolonged recession, there were actually fewer employees increasing their monthly contributions than decreasing their contributions. There was no sign of clear turn-around in 2001.

Second, as shown in Figure 14, over 70\% of new recruits of 1990 decided to participate in the ESOP. As Japan's Great Recession progressed, the figure continued to decline, again with a brief exception of 1996, and reached all time low of $11 \%$ in 2000, followed by evidence of a turn-around in 2001. It appears as if new recruits have became more careful about making commitments to the ESOP and hence JFIRM.

In short, it is fair to say that Japanese ESOPs clearly survived the unprecedented adverse financial shock of the bubble burst and the subsequent prolonged stagnation although Japanese workers appeared to have fine-tuned their level of commitment to ESOPs during those turbulent years.

\section{$\underline{\text { 7. Conclusions }}$}

This paper has provided new evidence on changes in the Japanese employment system (or lack thereof) with particular focus on the "lifetime employment" system after the bubble burst. The bulk of the paper has been devoted to taking advantage of our first access to micro data from the most recent Employment Status Survey (2002) as well as prior years of the ESS 
and providing new evidence on changes in the "lifetime employment" practice which is believed to serves as a foundation for many complementary elements of the Japanese employment system.

Overall, we have found evidence of the resilience of the Japanese employment system. Job stability of regular employees did not fall much during the first five years of Japan’s Great Recession. Our cohort analysis of narrowly-defined "lifetime employment” workers (new school graduate hires) has also pointed to the relative stability of the size of the "lifetime employment" cohort. To be consistent with the enduring nature of the 'lifetime employment” system, we have also found some evidence for the buoyancy of other complementary elements of the Japanese employment system.

This, however, does not mean the complete rigidity of the Japanese employment system. Apparently the Japanese employment system has evolved in response to Japan’s prolonged stagnation. First, job stability of regular employees eventually fell during the final years of the Great Recession. It took years yet the magnitude of the fall turned out to be considerable and for some groups of workers it was large (the ten-year job retention rate of female regular employees age 30-35 with 0-5 years of tenure fell from 68 percent in the 1982-1992 period to 43 percent in the 1992-2002 period). Second, the burden of downsizing during Japan’s prolonged stagnation fell disproportionately on women as opposed to men and on high-school graduates as opposed to college graduates. The biggest "losers" appear to be female regular employees over age 30 with relatively short tenure working in large firms.

What do all these things mean to the Japanese economy? We believe that the Japanese employment system developed over time during the postwar era and was well-established and deep-rooted in the Japanese society as a coherent cluster of complementary employment practices by the end of the high growth period. It probably contributed significantly to the rise of 
the Japanese economy (Aoki, 1990, Koike, 2005, Morita, 2005).

Such institutional complementarity tends to cause the Japanese employment system not to respond immediately to external shocks (Aoki, 2000). Instinctive and hasty changes even in one element of the Japanese employment system may cause the whole system to halt due to the intricate complementary interplay between the changing element and the remaining elements of the system. As such, deliberate and prudent responses are more reflective of the nature of the Japanese system. That job stability started to change only after years of prolonged stagnation appears to be consistent with the view that the Japanese employment system is a coherent cluster of practices with strong institutional complementarity. For instance, a rushed decision to break implicit long-term employment contracts and terminate some of their "lifetime employment" workers will undermine incentive for the remaining "lifetime employment" workers to continue to invest in firm-specific human capital, and produce and share with their supervisors valuable firm-specific local knowledge. Furthermore, such a rushed decision may have a lasting negative reputational effect on prospective employees in the future.

One of the key challenges to this type of system is how to make necessary downward employment adjustments in a downturn without jeopardizing the aforementioned incentive for the remaining "lifetime employment workers" and amplifying the negative reputational effect. In our view, a response to this challenge by the Japanese employment system has been to maintain the two-tier structure of "lifetime employment" workers consisting of (i) the original members of the "lifetime employment" system; and (ii) the expansion members. The original members are typically male regular employees who are new graduate hires. They have been the heart and soul of the Japanese employment system and the crucial depository of firm-specific human capital and local knowledge. On one hand, our retention rate estimates and cohort 
analysis confirm that this group of workers was effectively insulated from Japan's prolonged stagnation.

On the other hand, as some scholars suggest, during the high growth and bubble periods, the Japanese employment system was extended to cover groups of workers that had been excluded from the system in the past, such as female regular employees and mid-career hires (Moriguchi and Ono, 2004 and Ariga, Ohkusa and Brunello, 1999). In this paper we have provided corroborating evidence that job security of female regular employees and mid-career hires did not deteriorate immediately following the bubble burst and that in fact it was after five years of prolonged stagnation that such expansion members finally started experiencing the weakening of their job securities. This suggests that these workers were indeed admitted to the "lifetime employment” club before the burst of the bubble.

Such expansion members of the "lifetime employment" system probably started to invest in firm-specific human capital and produce firm-specific local knowledge and share it with the firm as a result of newly granted admissions to the "lifetime employment" system. The cost of reneging on implicit long-term contracts with such expansion members is, however, still substantially lower than the cost of doing so with the original members since the amount of firmspecific human capital investment and firm-specific local knowledge production are still smaller for the expansion members than for the original members. Moreover, the breach of the implicit long-term contracts has both immediate adverse incentive effect on the remaining members and lasting negative reputational effect on prospective members in the future. Such adverse effects of contract breach are also likely to be smaller when the victims of such contract breach are the expansion members rather than the original members.

In light of the aforementioned difference in the cost of contract breach, it appears to be 
rational for Japanese firms in dire need for employment adjustment to withdraw their promise of job security from the expansion members of the "lifetime employment" system while continuing to honor their promise of job security to the original members. In other words, the expansion members appeared to have served as an elaborate shock absorber and helped Japanese firms honor their promise of job security to the original members of the "lifetime employment" system, which in turn contributes to the stability of the Japanese employment system.

The 1998 revision of the Labor Standards Law could be viewed as the government facilitating Japanese firms' attempts to nullify the "lifetime employment” membership of their expansion members by offering their employees multi-year fixed contracts rather than traditional indefinite contracts. We conjecture that both Japanese employers and unions wanted the 1998 revision, for both of them were interested in preserving the lifetime employment system for its core members (we call them the "original” members), and that the 1998 revision was considered a useful tool for Japanese firms to nullify the membership of the "expansion” members (women and mid-career hires) since the 1998 revision allows for multi-year fixed contracts as an alternative to traditional indefinite contracts. While we have no conclusive evidence to prove our conjecture, according to Japanese experts on the labor law system in Japan, the 1998 revision was initiated originally in 1993 by the Study Group on the Labor Standards Law that was created to advise informally the Minister of Labor. The Study Group indeed cited rising needs for such multi-year fixed contract workers expressed by Japanese employers and unions. The original proposal was modified several times and finally passed by the Japanese Diet in 1998 as part of the overall deregulation efforts by the Japanese governments (Karatsu, 2004).

Finally, while providing rigorous evidence on the impact of Japanese labor market institutions such as the "lifetime employment" system on unemployment and/or growth is 
beyond the scope of the paper, we conduct two preliminary analyses to shed some light on this challenging yet important issue.

First, we apply the methodology developed by Gordon (1982) to up-to-date monthly time-series data covering August 1984 - December 2002, and examine whether wage bill fluctuations are now more correlated with employment changes than they were historically. Table 8 summarizes the results. Since OECD data on employment and hours worked are readily available only annually, we use the original monthly data from Maikin (Monthly Survey on Labor). Unfortunately industry classification changed in August of 1984, and data on manufacturing wage, hours and employment prior to August 1984 are not comparable to those after August 1984. Based on our analysis of the ESS data, we calculate standard deviations of rates of change of monthly manufacturing wage rates, monthly hours worked, and monthly employment for the four time periods: (i) August 1984 - December 1987; (ii) January 1988 December 1992; (iii) January 1993 - December 1997; and (iv) January 1997 - December 2002. ${ }^{24}$ Row (8) of the table shows standard deviation of the rate of change of wage bill divided by standard deviation of the rate of change of employment for each of the four time periods, which measures the relative importance of wage bill fluctuations to employment fluctuations. There appears to be no clear evidence for the diminishing importance of wage bill fluctuations to employment fluctuations (or the rising importance of employment fluctuations to wage bill fluctuations). The lack of evidence on the rising importance of employment fluctuations relative to wage bill fluctuations appears to be consistent with the notion of institutional complementarity and the resulting relative resilience of the Japanese employment system.

Second, to study some possible correlation between growth and the "lifetime

${ }^{24}$ The size of standard deviation is not comparable to Gordon's original results, for we use monthly data while Gordon used quarterly data. 
employment” system, we obtain annual TFP growth rate series from JIP database (the annual TFP growth data series are available consistently for 1983 - 2005 yet unfortunately only for two industry categories, manufacturing and restaurants). We also acquire the corresponding annual series on average tenure for the same time period from the Basic Survey on Wage Structure. In Figure 15, we plot all annual observations (X, Y) where $\mathrm{X}=$ annual growth rate of TFP and $\mathrm{Y}=$ annual change in average tenure. The figure does not show any significant correlation between $\mathrm{X}$ and $\mathrm{Y}$, pointing to strong needs for a deeper understanding of possible interplay between the "lifetime employment" system and growth and a more rigorous empirical analysis. 
References

Aoki, Masahiko. Information, Corporate Governance, and Institutional Diversity: Competitiveness in Japan, the USA, and the Transitional Economies. Oxford and New York: Oxford University Press, 2000.

. "Toward an Economic Model of the Japanese Firm." Journal of Economic Literature, 1990, 28(1), pp. 1-27.

Ariga, Kenn. "From Golden Eggs to Rotten Apples: Changing Landscape of the Market for New High School Graduates in Japan," Kyoto University, 2005.

Ariga, Kenn; Ohkusa, Yasushi and Brunello, Giorgio. "Fast Track: Is It in the Genes? The Promotion Policy of a Large Japanese Firm." Journal of Economic Behavior and Organization, 1999, 38(4), pp. 385-402.

Ariga, Kenn and Okazawa, Ryousuke. "Labor Immobility in Japan: Its Causes and Consequences," the ESRI Conference on Japan's Bubble, Deflation and Long-term Stagnation. Federal Reserve Board San Francisco, 2007.

Carmichael, H. Lorne and MacLeod, W. Bentley. "Multiskilling, Technical Change and the Japanese Firm." Economic Journal, 1993, 103(416), pp. 142-60.

Chuma, Hiroyuki. "Employment Adjustments in Japanese Firms During the Current Crisis." Industrial Relations, 2002, 41(4), pp. 653-82.

. "Is Japan's Long-Term Employment System Changing?," T. Tachibanaki and I. Ohashi, Internal Labour Markets, Incentives and Employment. New York, London: St. Martin's Press/Macmillan Press, 1998, 225-68.

Dore, Ronald. "The End of Jobs for Life? Corporate Employment Systems: Japan and Elsewhere," London School of Economics, Centre for Economic Performance Occasional Paper: 11, 1996.

Edwards, Linda N. and Pasquale, Margaret K. "Women's Higher Education in Japan: Family Background, Economic Factors, and the Equal Employment Opportunity Law." Journal of the Japanese and International Economies, 2003, 17(1), pp. 1-32.

Farber, Henry S. "Are Lifetime Jobs Disappearing? Job Duration in the United States, 19731993," Labor statistics measurement issues. Chicago and London: University of Chicago Press, 1998, 157-203.

. "Labor Market Adjustment to Globalization: Long-Term Employment in the United States and Japan," Paper presented by the Trans Pacific Labor Seminar (organized by Takao Kato and Peter Kuhn). Santa Barbara, CA, 2007.

Genda, Yuji. "Who Really Lost Jobs in Japan? Youth Employment in an Aging Japanese Society," S. Ogura, T. Tachibanaki and D. A. Wise, Labor Markets and Firm Benefit Policies in Japan and the United States. Chicago and London: University of Chicago Press, 2003, 103-33.

Genda, Yuji and Rebick, Marcus E. "Japanese Labour in the 1990s: Stability and Stagnation." Oxford Review of Economic Policy, 2000, 16(2), pp. 85-102.

Gordon, Robert J. "Why U.S. Wage and Employment Behavior Differs from That in Britain and Japan." Economic Journal, 1982, 92(365), pp. 13-44.

Hall, Robert E. "The Importance of Lifetime Jobs in the U.S. Economy." American Economic Review, 1982, 72(4), pp. 716-24. 
Hashimoto, Masanori and Raisian, John. "Employment Tenure and Earnings Profiles in Japan and the United States." American Economic Review, 1985, 75(4), pp. 721-35.

Higuchi, Yoshio. Koyo to Shitsugyo No Keizaigaku (Economics of Employment and Unemployment). Tokyo: Nihon Keizai Shinbunsha, 2001.

Itoh, Hideshi. "Japanese Human Resource Management from the Viewpoint of Incentive Theory," M. Aoki and R. Dore, The Japanese Firm: The Sources of Competitive Strength. Oxford and New York: Oxford University Press, 1994, 233-64.

Jones, Derek C. and Kato, Takao. "The Productivity Effects of Employee Stock-Ownership Plans and Bonuses: Evidence from Japanese Panel Data." American Economic Review, 1995, 85(3), pp. 391-414.

Kambayashi, Ryo and Kawaguchi, Daiji. "Yon-Youken Handan No Toukeiteki Bunseki: 1975-1994 (Statistical Analysis Of "Four Main Standards": 1975-1994)," R. Kambayashi, Kaiko Kisei No Hou to Keizai (Law and Economics of Employment Protection). Tokyo: Nihon Hyoron Sha, 2008, 157-74.

Karatsu, Hiroshi "New Developments in Legal Regulations Pertaining to Dismissal \& FixedTerm Employment Contracts in the Labour Standards (Amendment) Law 2003." The Japanese Journal of Labour Studies, 2004, No. 523.

Kato, Takao. "The End of Lifetime Employment in Japan? Evidence from National Surveys and Field Research." Journal of the Japanese and International Economies, 2001, 15(4), pp. 489-514.

. "The Recent Transformation of Participatory Employment Practices," S. Ogura, T. Tachibanaki and D. Wise, NBER Conference Report Labor Markets and Firm Benefit Policies in Japan and the United States. Chicago: University of Chicago Press, 2003, 3980.

Kato, Takao and Morishima, Motohiro. "The Productivity Effects of Participatory Employment Practices: Evidence from New Japanese Panel Data." Industrial Relations, 2002, 41(4), pp. 487-520.

Koike, Kazuo. Shigoto No Keizaigaku (Economics of Work). Tokyo: Toyo Keizai, 2005. . Shokuba No Rodokumiai to Sanka (Unions at Workplace and Participation). Tokyo: Toyo Keizai (Oriental Economist), 1977.

Levine, David I. Reinventing the Workplace: How Business and Employees Can Both Win. Washington, D.C.: Brookings Institution, 1995.

Miyanaga, Wataru. "Labor's Share and Adjustment of Wages and Employment," Development Bank of Japan Research Report No. 27, 2002.

Moriguchi, Chiaki and Ono, Hiroshi. "Japanese Lifetime Employment: A Century's Perspective," EIJS Working Paper Series No. 205, 2004.

Morita, Hodaka. "Choice of Technology and Labour Market Consequences: An Explanation of U.S.-Japanese Differences." Economic Journal, 2001, 111(468), pp. 29-50.

. "Multi-Skilling, Delegation and Continuous Process Improvement: A Comparative Analysis of Us-Japanese Work Organizations." Economica, 2005, 72(285), pp. 69-93.

Nakata, Yoshifumi and Takehiro, Ryoji. "Total Labor Costs and the Employment Adjustment Behavior of Large Japanese Firms," S. Ogura, T. Tachibanaki and D. A. Wise, Labor Markets and Firm Benefit Policies in Japan and the United States. Chicago and London: NBER Conference Report series; University of Chicago Press, 2003, 135.

Neumark, David, ed. On the Job: Is Long-Term Employment a Thing of the Past? New York: Russell Sage Foundation, 2000. 
Ohkusa, Yasushi and Ohtake, Fumio. "The Productivity Effects of Information Sharing, Profit Sharing, and ESOPs." Journal of the Japanese and International Economies, 1997, 11(3), pp. 385-402.

Ono, Hiroshi. "Lifetime Employment in Japan: Concepts and Measurements," SSE/EFI Working Paper Series in Economics and Finance No. 624, 2007.

Ono, Hiroshi and Rebick, Marcus E. "Constraints on the Level and Efficient Use of Labor in Japan," National Bureau of Economic Research, Inc, NBER Working Papers: 9484, 2003.

Rebick, Marcus. The Japanese Employment System: Adapting to a New Economic Environment. Oxford and New York: Oxford University Press, 2005.

Suruga, Terukazu. "Employment Adjustment in Japanese Firms: Negative Profits and Dismissals," O. Isao and T. Tachibanaki, Internal Labour Markets, Incentives and Employment, New York: St. Martin's Press, 1998, 196-221.

Tachibanaki, Toshiaki. "Labor Mobility and Job Tenure," M. Aoki, the Economic Analysis of the Japanese Firm. Contributions to Economic Analysis series, no. 151. New York; Amsterdam and Oxford: North Holland; distributed in the U.S. and Canada by Elsevier Science, New York, 1984, 77-102.

Tsuru, Tsuyoshi; Abe, Masahiro and Kubo, Katsuyuki. Nihon Kigyo No Jinji Kaikaku (Personnel Reform in Japanese Firms). Tokyo: Oriental Economist, 2005. 
Table 1 Ten-year Job Retention Rates of Regular Employees for 1982-92, 1987-97, and 1992-2002:

All regular employees

\begin{tabular}{|c|c|c|c|c|c|c|c|c|c|c|}
\hline Age & Tenure & $\begin{array}{c}\text { percent of } \\
\text { population } \\
1982 \\
\end{array}$ & $\begin{array}{c}10 \text {-year job } \\
\text { retention rate (\%) } \\
1982-1992(\mathrm{~A}) \\
\end{array}$ & $\begin{array}{c}\text { percent of } \\
\text { population } \\
1987 \\
\end{array}$ & $\begin{array}{c}10 \text {-year job } \\
\text { retention rate }(\%) \\
1987-1997(\mathrm{~B}) \\
\end{array}$ & \begin{tabular}{|c} 
percent of \\
population \\
1992 \\
\end{tabular} & $\begin{array}{c}10-\text { year job } \\
\text { retention rate }(\%) \\
1992-2002(\mathrm{C}) \\
\end{array}$ & $C-A$ & $B-A$ & $C-B$ \\
\hline $15-19$ & $0-4$ & 13.60 & 38.80 & 11.22 & 38.83 & 10.71 & 42.82 & 4.02 & 0.03 & 3.99 \\
\hline $20-24$ & $0-4$ & 46.33 & 40.84 & 46.31 & 40.32 & 49.07 & 37.93 & -2.92 & -0.53 & -2.39 \\
\hline $25-29$ & $0-4$ & 22.69 & 54.15 & 24.13 & 55.71 & 29.57 & 52.15 & -2.00 & 1.56 & -3.55 \\
\hline $30-34$ & $0-4$ & 9.98 & 56.26 & 10.83 & 56.22 & 13.24 & 51.83 & -4.43 & -0.04 & -4.39 \\
\hline 35-39 & $0-4$ & 7.71 & 63.40 & 8.11 & 59.93 & 9.67 & 49.27 & -14.13 & -3.48 & -10.66 \\
\hline $40-44$ & $0-4$ & 6.56 & 65.51 & 6.82 & 63.74 & 7.61 & 51.86 & -13.65 & -1.77 & -11.88 \\
\hline $20-24$ & $5+$ & 9.74 & 39.19 & 9.73 & 37.29 & 7.62 & 29.84 & -9.35 & -1.90 & -7.45 \\
\hline $25-29$ & $5+$ & 30.43 & 61.96 & 32.31 & 57.02 & 31.54 & 50.24 & -11.72 & -4.94 & -6.78 \\
\hline $30-34$ & $5+$ & 35.23 & 75.85 & 37.31 & 73.75 & 38.42 & 68.07 & -7.77 & -2.09 & -5.68 \\
\hline 35-39 & $5+$ & 35.91 & 79.53 & 36.61 & 79.73 & 38.31 & 73.08 & -6.45 & 0.20 & -6.65 \\
\hline $40-44$ & $5+$ & 36.08 & 78.60 & 37.32 & 78.19 & 37.87 & 69.73 & -8.86 & -0.40 & -8.46 \\
\hline
\end{tabular}

Source: the Employment Status Survey, 1982, 1987, 1992, 1997 and 2002 
Table 2A Ten-year Job Retention Rates of Regular Employees for 1982-92, 1987-97, and 1992-2002:

Male Regular Employees

\begin{tabular}{|c|c|c|c|c|c|c|c|c|c|c|}
\hline Age & Tenure & $\begin{array}{l}\text { percent of } \\
\text { population } \\
1982 \\
\end{array}$ & $\begin{array}{c}\text { 10-year job } \\
\text { retention rate (\%) } \\
1982-1992(\mathrm{~A})\end{array}$ & $\begin{array}{c}\text { percent of } \\
\text { population } \\
1987 \\
\end{array}$ & $\begin{array}{c}\text { 10-year job } \\
\text { retention rate (\%) } \\
1987-1997(\mathrm{~B}) \\
\end{array}$ & \begin{tabular}{|c} 
percent of \\
population \\
1992 \\
\end{tabular} & $\begin{array}{c}\text { 10-year job } \\
\text { retention rate }(\%) \\
1992-2002(\mathrm{C})\end{array}$ & $C-A$ & $B-A$ & $C-B$ \\
\hline $15-19$ & $0-4$ & 12.86 & 58.91 & 10.87 & 57.48 & 11.19 & 59.02 & 0.11 & -1.43 & 1.54 \\
\hline $20-24$ & $0-4$ & 44.04 & 64.16 & 44.62 & 61.64 & 46.65 & 56.73 & -7.43 & -2.52 & -4.91 \\
\hline $25-29$ & $0-4$ & 32.11 & 60.31 & 33.51 & 64.98 & 38.26 & 63.14 & 2.84 & 4.67 & -1.83 \\
\hline $30-34$ & $0-4$ & 13.42 & 54.48 & 15.15 & 55.52 & 17.65 & 58.13 & 3.65 & 1.04 & 2.60 \\
\hline $35-39$ & $0-4$ & 8.77 & 58.55 & 10.03 & 54.19 & 11.75 & 50.05 & -8.50 & -4.36 & -4.13 \\
\hline $40-44$ & $0-4$ & 6.69 & 60.40 & 7.75 & 58.67 & 8.19 & 52.38 & -8.02 & -1.73 & -6.28 \\
\hline $20-24$ & $5+$ & 10.98 & 56.13 & 10.68 & 54.09 & 8.77 & 40.99 & -15.14 & -2.04 & -13.10 \\
\hline $25-29$ & $5+$ & 42.88 & 69.02 & 43.62 & 65.49 & 40.85 & 60.27 & -8.75 & -3.53 & -5.23 \\
\hline $30-34$ & $5+$ & 56.94 & 77.01 & 58.51 & 74.88 & 58.67 & 70.21 & -6.79 & -2.12 & -4.67 \\
\hline $35-39$ & $5+$ & 58.33 & 80.51 & 58.22 & 80.12 & 58.92 & 75.00 & -5.51 & -0.39 & -5.12 \\
\hline $40-44$ & $5+$ & 56.22 & 81.01 & 58.07 & 80.14 & 57.41 & 72.10 & -8.91 & -0.87 & -8.04 \\
\hline
\end{tabular}

Source: the Employment Status Survey, 1982, 1987, 1992, 1997 and 2002 
Table 2B Ten-year Job Retention Rates of Regular Employees for 1982-92, 1987-97, and 1992-2002:

Female Regular Employees

\begin{tabular}{|c|c|c|c|c|c|c|c|c|c|c|}
\hline Age & Tenure & $\begin{array}{l}\text { percent of } \\
\text { population } \\
1982\end{array}$ & $\begin{array}{c}10-\text { year job } \\
\text { retention rate (\%) } \\
1982-1992(\mathrm{~A})\end{array}$ & $\begin{array}{c}\text { percent of } \\
\text { population } \\
1987\end{array}$ & $\begin{array}{c}\text { 10-year job } \\
\text { retention rate (\%) } \\
1987-1997(\mathrm{~B})\end{array}$ & $\begin{array}{l}\text { percent of } \\
\text { population } \\
1992\end{array}$ & $\begin{array}{c}\text { 10-year job } \\
\text { retention rate }(\%) \\
1992-2002(\mathrm{C})\end{array}$ & $C-A$ & $B-A$ & $C-B$ \\
\hline $15-19$ & $0-4$ & 14.38 & 20.4 & 11.57 & 20.9 & 10.20 & 24.7 & 4.27 & 0.46 & 3.81 \\
\hline $20-24$ & $0-4$ & 48.65 & 19.3 & 48.06 & 20.1 & 51.57 & 20.6 & 1.26 & 0.74 & 0.52 \\
\hline $25-29$ & $0-4$ & 13.21 & 38.7 & 14.61 & 34.0 & 20.72 & 31.8 & -6.95 & -4.73 & -2.22 \\
\hline $30-34$ & $0-4$ & 6.50 & 60.0 & 6.45 & 58.0 & 8.75 & 39.3 & -20.74 & -2.00 & -18.74 \\
\hline $35-39$ & $0-4$ & 6.66 & 69.8 & 6.18 & 69.4 & 7.56 & 48.2 & -21.63 & -0.46 & -21.17 \\
\hline $40-44$ & $0-4$ & 6.43 & 70.7 & 5.89 & 70.4 & 7.03 & 51.3 & -19.42 & -0.30 & -19.12 \\
\hline $20-24$ & $5+$ & 8.49 & 16.8 & 8.76 & 16.4 & 6.44 & 14.5 & -2.37 & -0.44 & -1.92 \\
\hline $25-29$ & $5+$ & 17.90 & 44.5 & 20.83 & 38.9 & 22.04 & 31.6 & -12.95 & -5.64 & -7.31 \\
\hline $30-34$ & $5+$ & 13.33 & 71.1 & 15.83 & 69.8 & 17.79 & 61.7 & -9.35 & -1.21 & -8.14 \\
\hline $35-39$ & $5+$ & 13.47 & 76.1 & 14.84 & 78.7 & 17.43 & 67.4 & -8.62 & 2.65 & -11.27 \\
\hline $40-44$ & $5+$ & 16.05 & 71.7 & 16.62 & 72.6 & 18.20 & 63.4 & -8.25 & 0.87 & -9.12 \\
\hline
\end{tabular}

Source: the Employment Status Survey, 1982, 1987, 1992, 1997 and 2002 
Table 3A Ten-year Job Retention Rates of Regular Employees for 1982-92, 1987-97, and 1992-2002:

Male Regular Employees with College Degrees

\begin{tabular}{|c|c|c|c|c|c|c|c|c|c|c|}
\hline Age & Tenure & \begin{tabular}{|c} 
percent of \\
population \\
1982 \\
\end{tabular} & $\begin{array}{c}\text { 10-year job } \\
\text { retention rate }(\%) \\
1982-1992(\mathrm{~A}) \\
\end{array}$ & \begin{tabular}{|c} 
percent of \\
population \\
1987 \\
\end{tabular} & $\begin{array}{c}\text { 10-year job } \\
\text { retention rate (\%) } \\
1987-1997(\mathrm{~B}) \\
\end{array}$ & $\mid \begin{array}{c}\text { percent of } \\
\text { population } \\
1992 \\
\end{array}$ & $\begin{array}{c}10 \text {-year job } \\
\text { retention rate }(\%) \\
1992-2002(\mathrm{C}) \\
\end{array}$ & $C-A$ & B - A & $C-B$ \\
\hline $20-24$ & $0-4$ & 15.00 & 83.50 & 14.83 & 86.60 & 17.05 & 67.03 & -16.47 & 3.11 & -19.57 \\
\hline $25-29$ & $0-4$ & 18.03 & 70.69 & 19.54 & 76.03 & 21.48 & 76.81 & 6.12 & 5.34 & 0.78 \\
\hline $30-34$ & $0-4$ & 3.56 & 59.59 & 5.65 & 62.03 & 7.23 & 67.52 & 7.93 & 2.44 & 5.50 \\
\hline $35-39$ & $0-4$ & 1.64 & 63.28 & 2.39 & 55.76 & 4.00 & 53.49 & -9.79 & -7.52 & -2.27 \\
\hline $40-44$ & $0-4$ & 0.86 & 55.06 & 1.36 & 60.09 & 1.93 & 53.40 & -1.66 & 5.03 & -6.69 \\
\hline $25-29$ & $5+$ & 11.51 & 71.25 & 15.98 & 68.90 & 15.27 & 56.33 & -14.91 & -2.34 & -12.57 \\
\hline $30-34$ & $5+$ & 17.92 & 79.56 & 24.50 & 78.27 & 28.37 & 76.47 & -3.08 & -1.29 & -1.80 \\
\hline $35-39$ & $5+$ & 15.53 & 84.80 & 19.24 & 82.24 & 24.71 & 81.67 & -3.13 & -2.56 & -0.57 \\
\hline $40-44$ & $5+$ & 12.84 & 81.68 & 15.66 & 83.55 & 17.89 & 78.50 & -3.18 & 1.87 & -5.05 \\
\hline
\end{tabular}

Source: the Employment Status Survey, 1982, 1987, 1992, 1997 and 2002 
Table 3B Ten-year Job Retention Rates of Regular Employees for 1982-92, 1987-97, and 1992-2002:

Male Regular Employees without College Degrees

\begin{tabular}{|c|c|c|c|c|c|c|c|c|c|c|}
\hline Age & Tenure & $\begin{array}{c}\text { percent of } \\
\text { population } \\
1982 \\
\end{array}$ & $\begin{array}{c}10 \text {-year job } \\
\text { retention rate (\%) } \\
1982-1992(\mathrm{~A}) \\
\end{array}$ & \begin{tabular}{|c|} 
percent of \\
population \\
1987 \\
\end{tabular} & $\begin{array}{c}\text { 10-year job } \\
\text { retention rate (\%) } \\
1987-1997(\mathrm{~B}) \\
\end{array}$ & \begin{tabular}{|c|} 
percent of \\
population \\
1992 \\
\end{tabular} & $\begin{array}{c}10 \text {-year job } \\
\text { retention rate }(\%) \\
1992-2002(\mathrm{C}) \\
\end{array}$ & $C-A$ & $B-A$ & $C-B$ \\
\hline $15-19$ & $0-4$ & 12.73 & 55.94 & 10.72 & 54.53 & 11.04 & 55.69 & -0.25 & -1.41 & 1.16 \\
\hline $20-24$ & $0-4$ & 29.02 & 53.87 & 29.73 & 48.99 & 29.38 & 51.06 & -2.80 & -4.88 & 2.07 \\
\hline $25-29$ & $0-4$ & 14.07 & 46.69 & 13.93 & 48.90 & 16.59 & 45.96 & -0.74 & 2.20 & -2.94 \\
\hline $30-34$ & $0-4$ & 9.85 & 52.19 & 9.50 & 51.26 & 10.36 & 51.74 & -0.45 & -0.93 & 0.48 \\
\hline $35-39$ & $0-4$ & 7.11 & 57.38 & 7.61 & 53.35 & 7.70 & 48.48 & -8.90 & -4.02 & -4.87 \\
\hline $40-44$ & $0-4$ & 5.82 & 60.46 & 6.38 & 58.33 & 6.22 & 51.94 & -8.52 & -2.13 & -6.39 \\
\hline $20-24$ & $5+$ & 10.44 & 56.02 & 10.11 & 53.99 & 8.23 & 41.62 & -14.40 & -2.03 & -12.37 \\
\hline $25-29$ & $5+$ & 31.35 & 68.09 & 27.60 & 63.25 & 25.43 & 62.91 & -5.18 & -4.84 & -0.35 \\
\hline $30-34$ & $5+$ & 38.99 & 75.49 & 33.94 & 72.17 & 30.12 & 64.55 & -10.94 & -3.33 & -7.61 \\
\hline 35-39 & $5+$ & 42.76 & 78.56 & 38.88 & 78.62 & 34.07 & 70.25 & -8.31 & 0.06 & -8.37 \\
\hline $40-44$ & $5+$ & 43.35 & 80.28 & 42.26 & 78.58 & 39.29 & 69.42 & -10.86 & -1.70 & -9.16 \\
\hline
\end{tabular}

Source: the Employment Status Survey, 1982, 1987, 1992, 1997 and 2002 
Table 4A Ten-year Job Retention Rates of Regular Employees for 1982-92, 1987-97, and 1992-2002:

Female Regular Employees with college degrees

\begin{tabular}{|c|c|c|c|c|c|c|c|c|c|c|}
\hline Age & Tenure & $\begin{array}{l}\text { percent of } \\
\text { population } \\
1982 \\
\end{array}$ & $\begin{array}{c}10 \text {-year job } \\
\text { retention rate }(\%) \\
1982-1992(\mathrm{~A}) \\
\end{array}$ & $\begin{array}{l}\text { percent of } \\
\text { population } \\
1987 \\
\end{array}$ & $\begin{array}{c}10 \text {-year job } \\
\text { retention rate }(\%) \\
1987-1997(\mathrm{~B}) \\
\end{array}$ & \begin{tabular}{|c} 
percent of \\
population \\
1992 \\
\end{tabular} & $\begin{array}{c}10 \text {-year job } \\
\text { retention rate }(\%) \\
1992-2002(\mathrm{C})\end{array}$ & $C-A$ & B - A & $C-B$ \\
\hline $20-24$ & $0-4$ & 21.46 & 25.69 & 22.74 & 24.25 & 27.20 & 23.66 & -2.02 & -1.44 & -0.58 \\
\hline $25-29$ & $0-4$ & 5.97 & 45.02 & 8.18 & 36.05 & 11.89 & 38.39 & -6.64 & -8.97 & 2.34 \\
\hline $30-34$ & $0-4$ & 1.12 & 64.48 & 1.90 & 57.52 & 3.48 & 43.41 & -21.07 & -6.96 & -14.11 \\
\hline 35-39 & $0-4$ & 0.56 & * & 1.03 & 61.99 & 2.03 & 53.48 & & & -8.51 \\
\hline $40-44$ & $0-4$ & 0.32 & $*$ & 0.58 & $*$ & 1.13 & 51.46 & & & \\
\hline $25-29$ & $5+$ & 6.81 & 52.94 & 9.61 & 45.46 & 10.87 & 30.93 & -22.01 & -7.48 & -14.53 \\
\hline $30-34$ & $5+$ & 4.22 & 81.96 & 7.37 & 79.54 & 9.81 & 67.47 & -14.49 & -2.42 & -12.07 \\
\hline 35-39 & $5+$ & 2.79 & 81.85 & 4.51 & 87.16 & 7.56 & 77.90 & -3.95 & 5.30 & -9.26 \\
\hline $40-44$ & $5+$ & 2.08 & 83.26 & 3.17 & 89.28 & 4.91 & 82.39 & -0.87 & 6.02 & -6.89 \\
\hline
\end{tabular}

Source: the Employment Status Survey, 1982, 1987, 1992, 1997 and 2002

Note: *Due to a small cell size the retention rate estimate is unreliable. 
Table 4B Ten-year Job Retention Rates of Regular Employees for 1982-92, 1987-97, and 1992-2002:

Female Regular Employees without college degrees

\begin{tabular}{|c|c|c|c|c|c|c|c|c|c|c|}
\hline Age & Tenure & $\begin{array}{c}\text { percent of } \\
\text { population } \\
1982 \\
\end{array}$ & $\begin{array}{c}10 \text {-year job } \\
\text { retention rate (\%) } \\
1982-1992(\mathrm{~A}) \\
\end{array}$ & \begin{tabular}{|c|} 
percent of \\
population \\
1987 \\
\end{tabular} & $\begin{array}{c}\text { 10-year job } \\
\text { retention rate (\%) } \\
1987-1997(\mathrm{~B}) \\
\end{array}$ & \begin{tabular}{|c|} 
percent of \\
population \\
1992 \\
\end{tabular} & $\begin{array}{c}10 \text {-year job } \\
\text { retention rate }(\%) \\
1992-2002(\mathrm{C}) \\
\end{array}$ & $C-A$ & $B-A$ & $C-B$ \\
\hline $15-19$ & $0-4$ & 14.03 & 18.56 & 11.17 & 17.68 & 9.86 & 20.90 & 2.34 & -0.87 & 3.22 \\
\hline $20-24$ & $0-4$ & 27.16 & 14.29 & 25.25 & 16.20 & 24.18 & 17.29 & 3.01 & 1.91 & 1.09 \\
\hline $25-29$ & $0-4$ & 7.23 & 33.07 & 6.37 & 31.37 & 8.77 & 22.76 & -10.31 & -1.70 & -8.61 \\
\hline $30-34$ & $0-4$ & 5.38 & 58.56 & 4.54 & 57.82 & 5.20 & 36.77 & -21.79 & -0.74 & -21.05 \\
\hline $35-39$ & $0-4$ & 6.09 & 69.40 & 5.12 & 70.78 & 5.48 & 46.65 & -22.75 & 1.38 & -24.13 \\
\hline $40-44$ & $0-4$ & 6.11 & 68.70 & 5.31 & 70.01 & 5.86 & 51.51 & -17.19 & 1.31 & -18.50 \\
\hline $20-24$ & $5+$ & 7.49 & 16.33 & 7.84 & 16.05 & 5.46 & 14.89 & -1.43 & -0.27 & -1.16 \\
\hline $25-29$ & $5+$ & 11.08 & 39.22 & 11.18 & 33.14 & 11.10 & 32.30 & -6.92 & -6.08 & -0.84 \\
\hline $30-34$ & $5+$ & 9.10 & 65.62 & 8.45 & 60.83 & 7.92 & 54.73 & -10.89 & -4.79 & -6.10 \\
\hline 35-39 & $5+$ & 10.67 & 74.12 & 10.29 & 74.80 & 9.80 & 59.50 & -14.63 & 0.67 & -15.30 \\
\hline $40-44$ & $5+$ & 13.96 & 69.64 & 13.43 & 68.10 & 13.20 & 56.58 & -13.06 & -1.54 & -11.52 \\
\hline
\end{tabular}

Source: the Employment Status Survey, 1982, 1987, 1992, 1997 and 2002 
Table 5A Ten-year Job Retention Rates of Regular Employees for 1982-92, 1987-97, and 1992-2002:

Male Regular Employees working in large firms (500 or more Employees)

\begin{tabular}{|c|c|c|c|c|c|c|c|c|c|c|}
\hline Age & Tenure & $\begin{array}{l}\text { percent of } \\
\text { population } \\
1982\end{array}$ & $\begin{array}{c}10-\text { year job } \\
\text { retention rate (\%) } \\
1982-1992(\mathrm{~A})\end{array}$ & $\begin{array}{c}\text { percent of } \\
\text { population } \\
1987\end{array}$ & $\begin{array}{c}\text { 10-year job } \\
\text { retention rate (\%) } \\
1987-1997(\mathrm{~B})\end{array}$ & $\begin{array}{l}\text { percent of } \\
\text { population } \\
1992\end{array}$ & $\begin{array}{c}\text { 10-year job } \\
\text { retention rate }(\%) \\
1992-2002(\mathrm{C})\end{array}$ & $C-A$ & $B-A$ & $C-B$ \\
\hline $15-19$ & $0-4$ & 4.34 & 80.93 & 2.78 & 84.90 & 3.87 & 73.10 & -7.84 & 3.97 & -11.81 \\
\hline $20-24$ & $0-4$ & 15.31 & 89.52 & 14.86 & 89.81 & 17.20 & 72.59 & -16.92 & 0.29 & -17.21 \\
\hline $25-29$ & $0-4$ & 10.21 & 87.90 & 11.79 & 95.25 & 15.65 & 83.41 & -4.49 & 7.35 & -11.84 \\
\hline $30-34$ & $0-4$ & 2.34 & 84.17 & 2.88 & 84.82 & 4.64 & 82.38 & -1.79 & 0.65 & -2.44 \\
\hline $35-39$ & $0-4$ & 1.24 & 92.77 & 1.42 & 86.45 & 2.37 & 66.69 & -26.08 & -6.33 & -19.75 \\
\hline $40-44$ & $0-4$ & 0.77 & $*$ & 1.08 & 84.99 & 1.44 & 56.84 & & & -28.15 \\
\hline $20-24$ & $5+$ & 3.85 & 69.06 & 4.50 & 62.79 & 2.89 & 51.91 & -17.15 & -6.27 & -10.88 \\
\hline $25-29$ & $5+$ & 18.57 & 81.94 & 18.93 & 77.39 & 18.30 & 72.68 & -9.26 & -4.55 & -4.71 \\
\hline $30-34$ & $5+$ & 25.57 & 89.40 & 25.93 & 89.83 & 27.11 & 86.47 & -2.93 & 0.43 & -3.36 \\
\hline $35-39$ & $5+$ & 26.87 & 92.45 & 25.95 & 91.92 & 26.68 & 90.41 & -2.04 & -0.54 & -1.50 \\
\hline $40-44$ & $5+$ & 25.81 & 89.69 & 27.13 & 86.45 & 26.03 & 82.74 & -6.96 & -3.24 & -3.71 \\
\hline
\end{tabular}

Source: the Employment Status Survey, 1982, 1987, 1992, 1997 and 2002

Note: $*$ Due to a small cell size the retention rate estimate is unreliable. 
Table 5B Ten-year Job Retention Rates of Regular Employees for 1982-92, 1987-97, and 1992-2002: Male Regular Employees Working in Medium Firms (30-499 Employees)

\begin{tabular}{|c|c|c|c|c|c|c|c|c|c|c|}
\hline Age & Tenure & $\begin{array}{l}\text { percent of } \\
\text { population } \\
1982 \\
\end{array}$ & $\begin{array}{c}10 \text {-year job } \\
\text { retention rate }(\%) \\
1982-1992(\mathrm{~A}) \\
\end{array}$ & $\begin{array}{l}\text { percent of } \\
\text { population } \\
1987 \\
\end{array}$ & $\begin{array}{c}10 \text {-year job } \\
\text { retention rate }(\%) \\
1987-1997(\mathrm{~B}) \\
\end{array}$ & \begin{tabular}{|c} 
percent of \\
population \\
1992 \\
\end{tabular} & $\begin{array}{c}10 \text {-year job } \\
\text { retention rate }(\%) \\
1992-2002(\mathrm{C})\end{array}$ & $C-A$ & B - A & $C-B$ \\
\hline $15-19$ & $0-4$ & 4.45 & 49.75 & 4.37 & 52.61 & 3.94 & 53.31 & 3.55 & 2.86 & 0.69 \\
\hline $20-24$ & $0-4$ & 15.74 & 56.43 & 17.25 & 51.90 & 17.09 & 53.54 & -2.89 & -4.53 & 1.64 \\
\hline $25-29$ & $0-4$ & 11.62 & 55.41 & 12.24 & 55.68 & 12.84 & 58.88 & 3.47 & 0.27 & 3.20 \\
\hline $30-34$ & $0-4$ & 5.30 & 59.30 & 6.31 & 55.55 & 7.24 & 54.89 & -4.41 & -3.75 & -0.67 \\
\hline 35-39 & $0-4$ & 3.57 & 63.83 & 4.17 & 58.17 & 5.08 & 52.03 & -11.80 & -5.66 & -6.14 \\
\hline $40-44$ & $0-4$ & 2.84 & 65.94 & 3.23 & 65.71 & 3.58 & 56.75 & -9.19 & -0.24 & -8.95 \\
\hline $20-24$ & $5+$ & 3.57 & 52.16 & 3.41 & 51.29 & 3.22 & 37.02 & -15.14 & -0.86 & -14.27 \\
\hline $25-29$ & $5+$ & 13.02 & 65.61 & 14.19 & 64.09 & 13.45 & 54.54 & -11.06 & -1.52 & -9.55 \\
\hline $30-34$ & $5+$ & 17.40 & 72.68 & 19.04 & 68.22 & 19.27 & 61.38 & -11.30 & -4.46 & -6.84 \\
\hline 35-39 & $5+$ & 18.15 & 75.55 & 18.54 & 77.59 & 19.25 & 65.62 & -9.93 & 2.04 & -11.96 \\
\hline $40-44$ & $5+$ & 17.86 & 77.43 & 18.51 & 79.83 & 18.60 & 65.58 & -11.85 & 2.39 & -14.24 \\
\hline
\end{tabular}

Source: the Employment Status Survey, 1982, 1987, 1992, 1997 and 2002 
Table 5C Ten-year Job Retention Rates of Regular Employees for 1982-92, 1987-97, and 1992-2002:

Male Regular Employees in Small Firms (fewer than 30 employees)

\begin{tabular}{|c|c|c|c|c|c|c|c|c|c|c|}
\hline Age & Tenure & \begin{tabular}{|c} 
percent of \\
population \\
1982 \\
\end{tabular} & $\begin{array}{c}10 \text {-year job } \\
\text { retention rate (\%) } \\
1982-1992(\mathrm{~A}) \\
\end{array}$ & \begin{tabular}{|c|} 
percent of \\
population \\
1987 \\
\end{tabular} & $\begin{array}{c}10 \text {-year job } \\
\text { retention rate (\%) } \\
1987-1997(\mathrm{~B}) \\
\end{array}$ & \begin{tabular}{|c|} 
percent of \\
population \\
1992 \\
\end{tabular} & $\begin{array}{c}10 \text {-year job } \\
\text { retention rate }(\%) \\
1992-2002(\mathrm{C}) \\
\end{array}$ & $C-A$ & $B-A$ & $C-B$ \\
\hline $15-19$ & $0-4$ & 4.06 & 44.61 & 3.72 & 42.16 & 3.35 & 48.99 & 4.38 & -2.45 & 6.83 \\
\hline $20-24$ & $0-4$ & 12.97 & 43.58 & 12.46 & 41.31 & 12.25 & 38.61 & -4.97 & -2.27 & -2.70 \\
\hline $25-29$ & $0-4$ & 10.27 & 38.24 & 9.48 & 38.98 & 9.70 & 35.58 & -2.66 & 0.74 & -3.40 \\
\hline $30-34$ & $0-4$ & 5.78 & 37.79 & 5.96 & 41.01 & 5.69 & 42.45 & 4.66 & 3.21 & 1.44 \\
\hline 35-39 & $0-4$ & 3.96 & 42.83 & 4.44 & 39.85 & 4.29 & 37.88 & -4.95 & -2.98 & -1.97 \\
\hline $40-44$ & $0-4$ & 3.07 & 44.53 & 3.43 & 43.35 & 3.16 & 45.35 & 0.82 & -1.17 & 1.99 \\
\hline $20-24$ & $5+$ & 3.56 & 46.14 & 2.75 & 42.89 & 2.66 & 33.49 & -12.65 & -3.24 & -9.41 \\
\hline $25-29$ & $5+$ & 11.27 & 51.60 & 10.50 & 45.72 & 9.04 & 43.64 & -7.96 & -5.88 & -2.08 \\
\hline $30-34$ & $5+$ & 13.96 & 59.40 & 13.51 & 55.19 & 12.21 & 47.12 & -12.28 & -4.21 & -8.07 \\
\hline 35-39 & $5+$ & 13.30 & 62.96 & 13.70 & 60.82 & 12.94 & 56.30 & -6.66 & -2.14 & -4.52 \\
\hline $40-44$ & $5+$ & 12.55 & 67.93 & 12.39 & 66.24 & 12.71 & 59.16 & -8.77 & -1.69 & -7.08 \\
\hline
\end{tabular}

Source: the Employment Status Survey, 1982, 1987, 1992, 1997 and 2002 
Table 6A Ten-year Job Retention Rates of Regular Employees for 1982-92, 1987-97, and 1992-2002:

Female Regular Employees in Large Firm (500 or more employees)

\begin{tabular}{|c|c|c|c|c|c|c|c|c|c|c|}
\hline Age & Tenure & $\begin{array}{c}\text { percent of } \\
\text { population } \\
1982 \\
\end{array}$ & $\begin{array}{c}10 \text {-year job } \\
\text { retention rate (\%) } \\
1982-1992(\mathrm{~A}) \\
\end{array}$ & \begin{tabular}{|c|} 
percent of \\
population \\
1987 \\
\end{tabular} & $\begin{array}{c}\text { 10-year job } \\
\text { retention rate (\%) } \\
1987-1997(\mathrm{~B}) \\
\end{array}$ & \begin{tabular}{|c|} 
percent of \\
population \\
1992 \\
\end{tabular} & $\begin{array}{c}10 \text {-year job } \\
\text { retention rate }(\%) \\
1992-2002(\mathrm{C}) \\
\end{array}$ & $C-A$ & $B-A$ & $C-B$ \\
\hline $15-19$ & $0-4$ & 5.30 & 29.44 & 3.66 & 27.76 & 3.53 & 31.94 & 2.50 & -1.68 & 4.18 \\
\hline $20-24$ & $0-4$ & 19.68 & 25.82 & 18.31 & 27.49 & 21.04 & 26.61 & 0.79 & 1.67 & -0.88 \\
\hline $25-29$ & $0-4$ & 3.72 & 53.58 & 4.35 & 44.24 & 6.72 & 46.27 & -7.32 & -9.35 & 2.03 \\
\hline $30-34$ & $0-4$ & 1.17 & 68.29 & 1.24 & 63.27 & 1.95 & 43.33 & -24.96 & -5.02 & -19.95 \\
\hline 35-39 & $0-4$ & 1.20 & 86.05 & 1.20 & 75.48 & 1.50 & 43.57 & -42.48 & -10.57 & -31.91 \\
\hline $40-44$ & $0-4$ & 1.04 & 83.62 & 1.15 & 68.50 & 1.24 & 45.45 & -38.17 & -15.11 & -23.05 \\
\hline $20-24$ & $5+$ & 3.84 & 18.16 & 4.01 & 18.64 & 2.46 & 17.15 & -1.01 & 0.48 & -1.49 \\
\hline $25-29$ & $5+$ & 9.15 & 52.76 & 10.50 & 45.12 & 10.65 & 35.90 & -16.85 & -7.63 & -9.22 \\
\hline $30-34$ & $5+$ & 5.64 & 79.64 & 7.87 & 79.09 & 8.33 & 72.66 & -6.98 & -0.55 & -6.43 \\
\hline $35-39$ & $5+$ & 4.32 & 85.58 & 5.57 & 91.85 & 7.67 & 79.64 & -5.94 & 6.27 & -12.21 \\
\hline $40-44$ & $5+$ & 4.61 & 77.87 & 5.21 & 83.10 & 6.27 & 76.00 & -1.87 & 5.22 & -7.09 \\
\hline
\end{tabular}

Source: the Employment Status Survey, 1982, 1987, 1992, 1997 and 2002 
Table 6B Ten-year Job Retention Rates of Regular Employees for 1982-92, 1987-97, and 1992-2002:

Female Regular Employees in Medium Firms (30-499 employees)

\begin{tabular}{|c|c|c|c|c|c|c|c|c|c|c|}
\hline Age & Tenure & $\begin{array}{c}\text { percent of } \\
\text { population } \\
1982 \\
\end{array}$ & $\begin{array}{c}\text { 10-year job } \\
\text { retention rate (\%) } \\
1982-1992(\mathrm{~A}) \\
\end{array}$ & $\begin{array}{c}\text { percent of } \\
\text { population } \\
1987 \\
\end{array}$ & $\begin{array}{c}\text { 10-year job } \\
\text { retention rate (\%) } \\
1987-1997(\mathrm{~B}) \\
\end{array}$ & \begin{tabular}{|c} 
percent of \\
population \\
1992 \\
\end{tabular} & $\begin{array}{c}\text { 10-year job } \\
\text { retention rate }(\%) \\
1992-2002(\mathrm{C})\end{array}$ & $C-A$ & $B-A$ & $C-B$ \\
\hline $15-19$ & $0-4$ & 5.83 & 15.91 & 5.13 & 18.63 & 4.48 & 22.54 & 6.62 & 2.71 & 3.91 \\
\hline $20-24$ & $0-4$ & 16.88 & 15.31 & 17.85 & 15.62 & 18.90 & 18.20 & 2.89 & 0.31 & 2.58 \\
\hline $25-29$ & $0-4$ & 4.54 & 29.20 & 5.19 & 28.51 & 7.55 & 25.26 & -3.94 & -0.70 & -3.24 \\
\hline $30-34$ & $0-4$ & 2.40 & 58.61 & 2.37 & 58.89 & 3.18 & 42.58 & -16.04 & 0.28 & -16.31 \\
\hline 35-39 & $0-4$ & 2.57 & 75.95 & 2.42 & 73.00 & 2.85 & 55.14 & -20.81 & -2.95 & -17.86 \\
\hline $40-44$ & $0-4$ & 2.72 & 75.70 & 2.38 & 80.10 & 3.02 & 56.53 & -19.17 & 4.40 & -23.57 \\
\hline $20-24$ & $5+$ & 2.86 & $*$ & 3.31 & 15.27 & 2.67 & $*$ & & & \\
\hline $25-29$ & $5+$ & 4.93 & 35.73 & 6.29 & 31.07 & 7.10 & 26.58 & -9.15 & -4.66 & -4.49 \\
\hline $30-34$ & $5+$ & 3.74 & 63.72 & 4.20 & 62.16 & 5.29 & 50.10 & -13.62 & -1.56 & -12.06 \\
\hline 35-39 & $5+$ & 3.98 & 73.50 & 4.18 & 76.76 & 4.81 & 56.83 & -16.67 & 3.26 & -19.93 \\
\hline $40-44$ & $5+$ & 5.46 & 67.41 & 5.25 & 73.09 & 5.79 & 56.84 & -10.57 & 5.68 & -16.25 \\
\hline
\end{tabular}

Source: the Employment Status Survey, 1982, 1987, 1992, 1997 and 2002

Note: $*$ Due to a small cell size the retention rate estimate is unreliable. 
Table 6C Ten-year Job Retention Rates of Regular Employees for 1982-92, 1987-97, and 1992-2002:

Female Regular Employees in Small Firm (fewer than 30 employees)

\begin{tabular}{|c|c|c|c|c|c|c|c|c|c|c|}
\hline Age & Tenure & $\begin{array}{c}\text { percent of } \\
\text { population } \\
1982 \\
\end{array}$ & $\begin{array}{c}\text { 10-year job } \\
\text { retention rate (\%) } \\
1982-1992(\mathrm{~A}) \\
\end{array}$ & $\begin{array}{c}\text { percent of } \\
\text { population } \\
1987 \\
\end{array}$ & $\begin{array}{c}\text { 10-year job } \\
\text { retention rate (\%) } \\
1987-1997(\mathrm{~B}) \\
\end{array}$ & \begin{tabular}{|c} 
percent of \\
population \\
1992 \\
\end{tabular} & $\begin{array}{c}\text { 10-year job } \\
\text { retention rate }(\%) \\
1992-2002(\mathrm{C})\end{array}$ & $C-A$ & $\mathrm{~B}-\mathrm{A}$ & $C-B$ \\
\hline $15-19$ & $0-4$ & 3.25 & 13.60 & 2.63 & 16.37 & 2.04 & 17.38 & 3.78 & 2.78 & 1.00 \\
\hline $20-24$ & $0-4$ & 12.06 & 14.48 & 11.57 & 15.41 & 11.12 & 13.80 & -0.68 & 0.93 & -1.61 \\
\hline 25-29 & $0-4$ & 4.95 & 36.24 & 4.98 & 30.71 & 6.31 & 23.79 & -12.45 & -5.54 & -6.92 \\
\hline $30-34$ & $0-4$ & 2.93 & 57.84 & 2.79 & 55.18 & 3.54 & 34.51 & -23.33 & -2.65 & -20.67 \\
\hline 35-39 & $0-4$ & 2.89 & 57.55 & 2.53 & 63.14 & 3.15 & 44.78 & -12.78 & 5.59 & -18.36 \\
\hline $40-44$ & $0-4$ & 2.67 & 60.69 & 2.35 & 62.96 & 2.75 & 48.81 & -11.88 & 2.28 & -14.16 \\
\hline $20-24$ & $5+$ & 1.80 & $*$ & 1.40 & $*$ & 1.27 & $*$ & & & \\
\hline $25-29$ & $5+$ & 3.83 & 36.15 & 3.97 & 34.82 & 4.19 & 29.01 & -7.14 & -1.33 & -5.81 \\
\hline $30-34$ & $5+$ & 3.95 & 65.64 & 3.71 & 58.59 & 4.06 & 54.25 & -11.38 & -7.05 & -4.34 \\
\hline 35-39 & $5+$ & 5.17 & 70.00 & 5.02 & 66.47 & 4.88 & 58.59 & -11.42 & -3.53 & -7.88 \\
\hline $40-44$ & $5+$ & 5.97 & 70.53 & 6.16 & 63.75 & 6.09 & 57.42 & -13.11 & -6.78 & -6.33 \\
\hline
\end{tabular}

Source: the Employment Status Survey, 1982, 1987, 1992, 1997 and 2002

Note: $*$ Due to a small cell size the retention rate estimate is unreliable. 
Table 7 Percentage of firms with weakened seniority wage systems: 1996, 1999, 2004 and 2007

\begin{tabular}{|c|c|c|c|c|}
\hline & $\begin{array}{l}\text { abolish } \\
\text { automatic } \\
\text { pay raise }\end{array}$ & \begin{tabular}{|l|} 
expand \\
part of \\
pay that \\
is \\
determined \\
by the \\
content of \\
tasks and \\
jobs
\end{tabular} & \begin{tabular}{|l|} 
expand \\
part of \\
pay that is \\
determined \\
by ability td \\
carry out \\
jobs
\end{tabular} & $\begin{array}{l}\text { expand } \\
\text { part of } \\
\text { pay that } \\
\text { is } \\
\text { determined } \\
\text { by } \\
\text { outcome } \\
\text { and } \\
\text { performance }\end{array}$ \\
\hline 1996 & $\overline{3.8}$ & 12.1 & \begin{tabular}{|c|}
15.7 \\
\end{tabular} & 15 \\
\hline 1999 & 10.5 & 11.3 & 15.8 & 15.5 \\
\hline 2004 & $\mathrm{~N} / \mathrm{A}$ & 15.5 & 17.6 & 20.7 \\
\hline 2007 & 7.1 & 23.3 & 22.1 & 23.7 \\
\hline
\end{tabular}

Source: General Survey on Working Conditions

(Former "General Survey on Wages and Working Hours System"), 1996, 1999, 2004 and 2007 
Table 8 Standard Deviations of rates of change of manufacturing wage rates, hours, and employment

\begin{tabular}{|c|c|c|c|c|c|}
\hline \multicolumn{2}{|c|}{ Period } & 1984:Aug & 1988:Jan - & 1993:Jan - & $\begin{array}{l}\text { 1998:Jan - } \\
\text { 2002.Dec }\end{array}$ \\
\hline \multicolumn{2}{|c|}{ Obs } & 40 & 60 & 60 & 60 \\
\hline Variable & & & & & \\
\hline (1) & $\mathrm{w}+\mathrm{h}+\mathrm{e}$ & 57.5 & 58.3 & 57.1 & 50.5 \\
\hline (2) & w & 60.2 & 56.9 & 54.5 & 49.1 \\
\hline (3) & $h+e$ & 7.8 & 8.8 & 8.7 & 7.8 \\
\hline (4) & h & 7.7 & 8.7 & 8.5 & 7.7 \\
\hline (5) & e & 0.7 & 0.9 & 0.7 & 0.6 \\
\hline Addenda & & & & & \\
\hline (6) & $(2) /(3)$ & 7.7 & 6.5 & 6.2 & 6.3 \\
\hline (7) & $(2) /(5)$ & 82.9 & 62.0 & 79.5 & 85.7 \\
\hline (8) & $(1) /(5)$ & 79.2 & 63.5 & 83.3 & 88.1 \\
\hline
\end{tabular}

$\mathrm{w}+\mathrm{h}+\mathrm{e}$ : rate of change of total amount of wage bill

w: rate of change of hourly wage ( = monthly earnings / monthly hours worked)

$\mathrm{h}+\mathrm{e}$ : rate of change of total man hour ( = employment * hour worked)

h: rate of change of monthly hour worked

e: rate of change of number of empolyee

All variables are for regular workers from Monthly Survey on Labor, Manufacturing over 30 employee. 
Figure 1 Gender gap in 10-year job retention rates for 1982-92, 1987-97, and 1992-2002:

Regular Employees

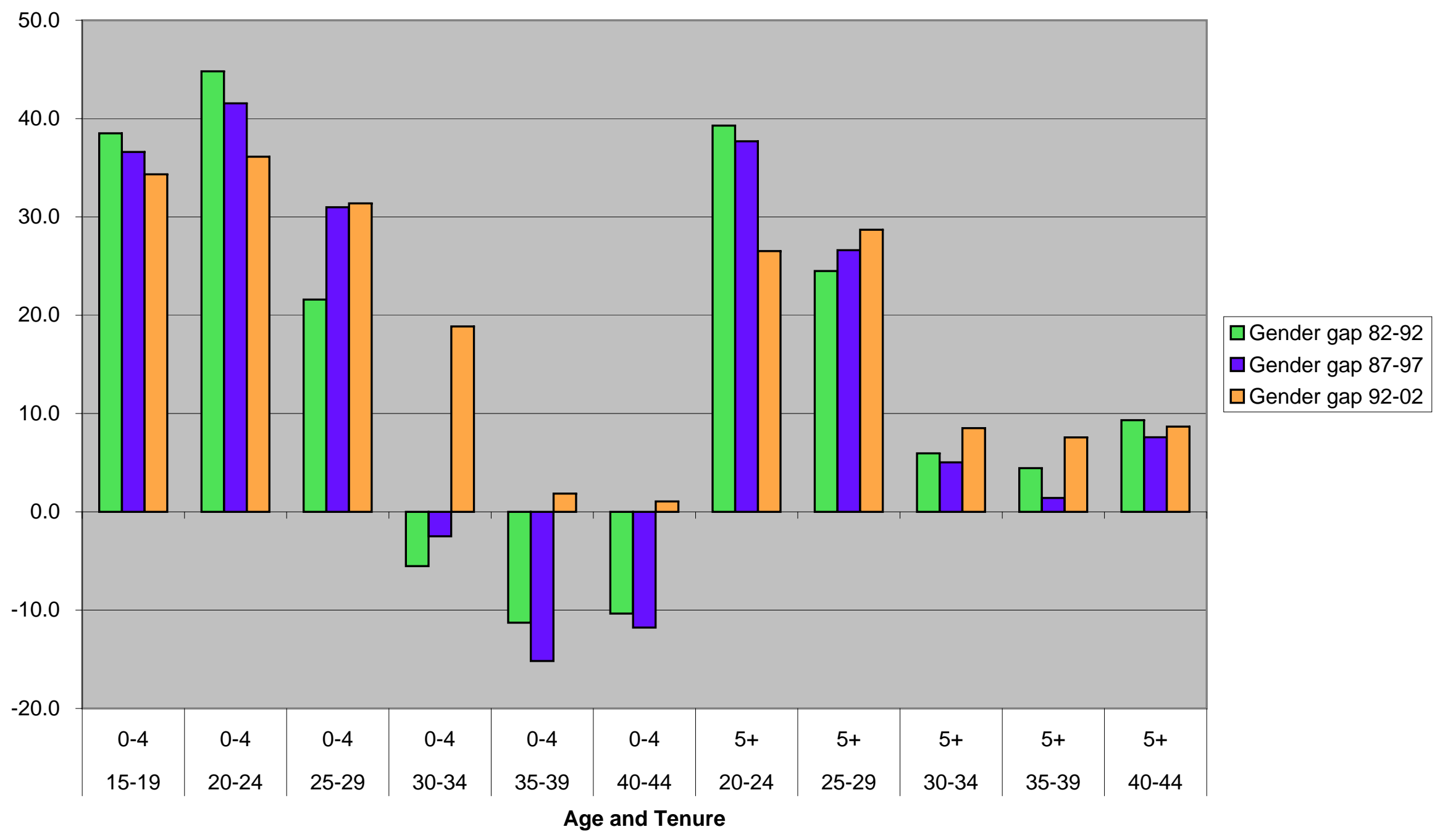


Figure 2 Education Gap in 10-year job retention rates for 1982-92, 1987-97, and 1992-2002:

Regular Male Employees

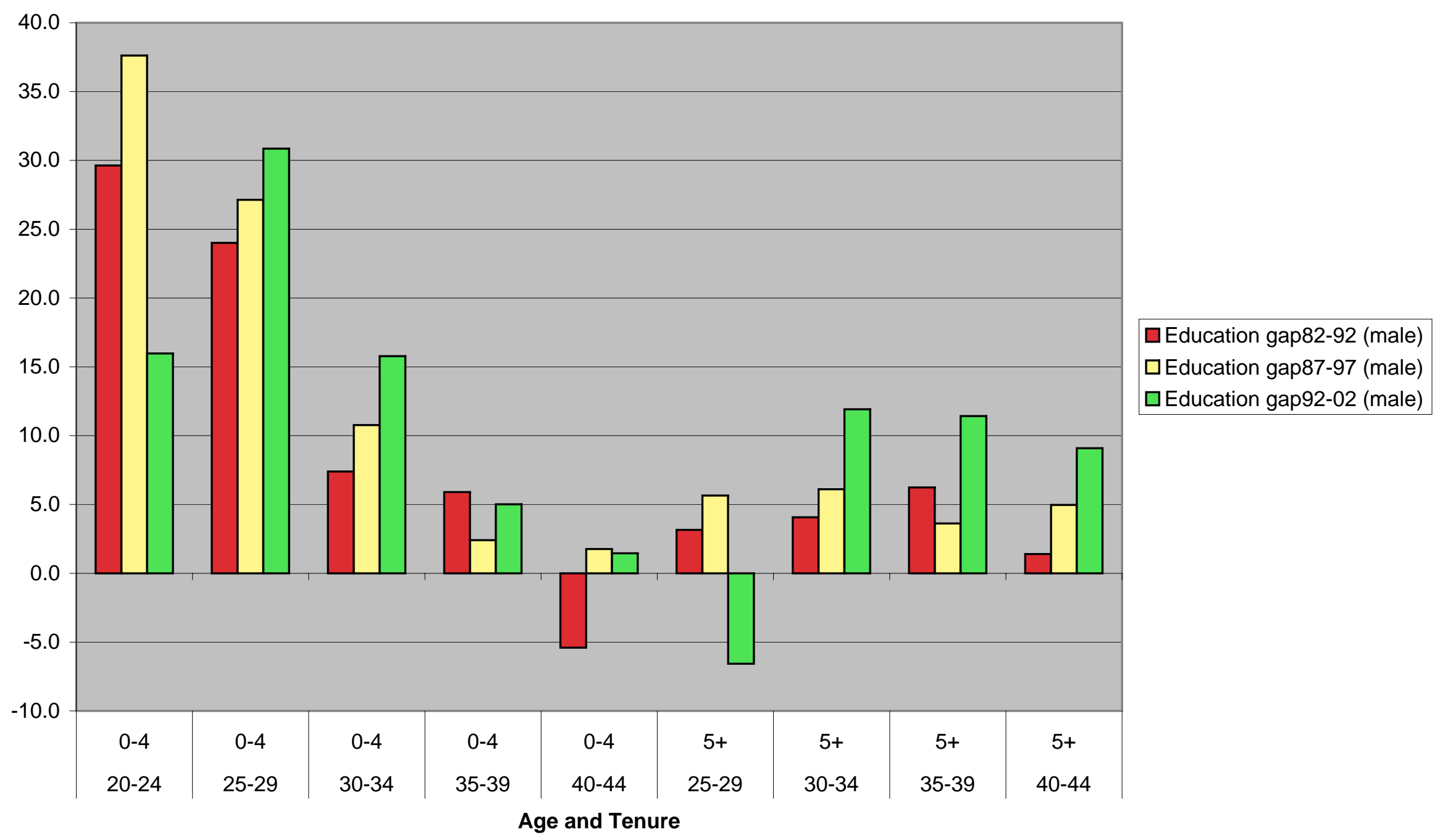


Figure 3A Gap in 10-year job retention rates between large and small firms

for 1982-92, 1987-97, and 1992-2002: Regular Male Employees

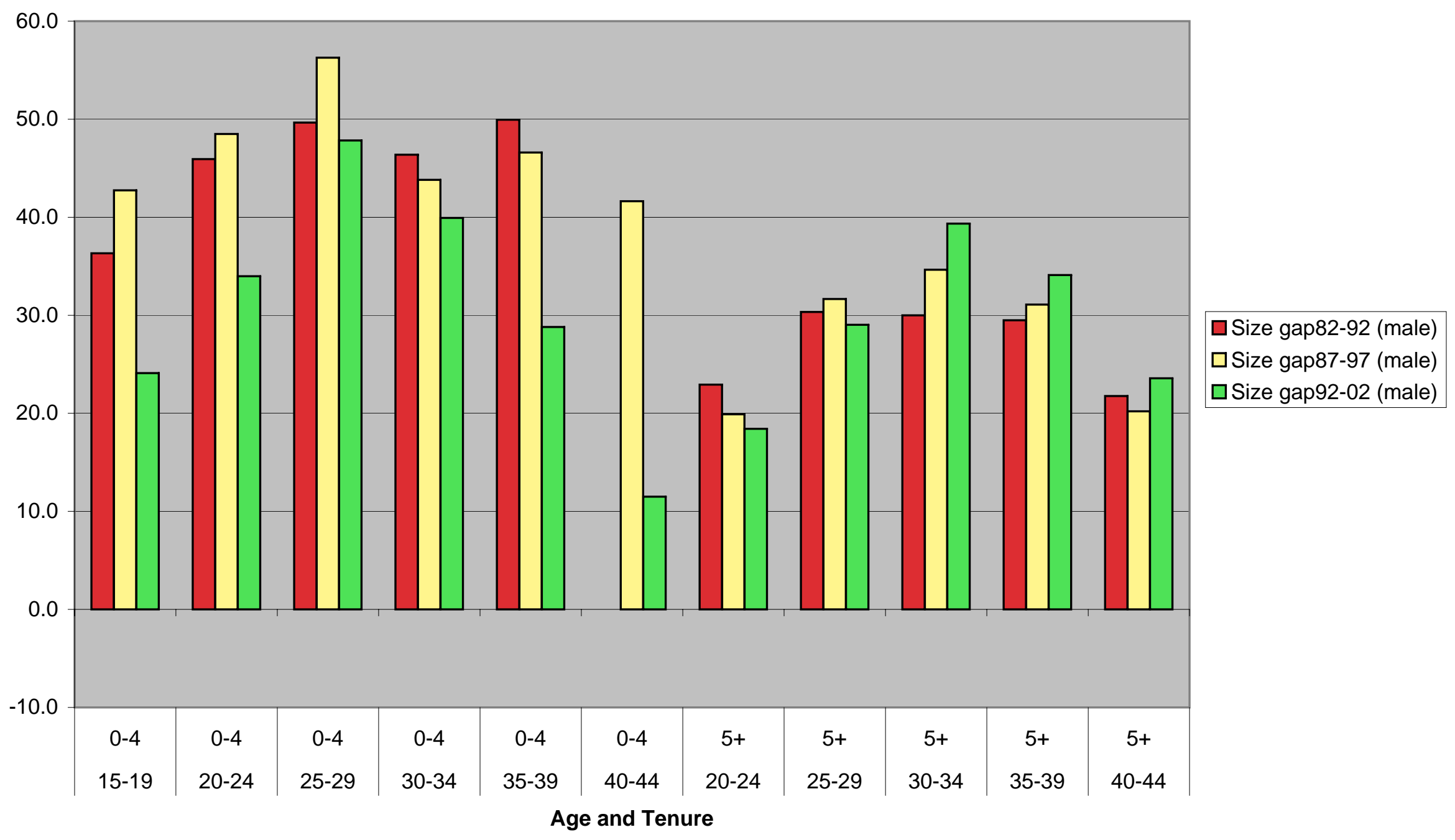


Figure 3B Gap in 10-year job retention rates between large and small firms for 1982-92, 1987-97, and 1992-2002: Regular Female Employees

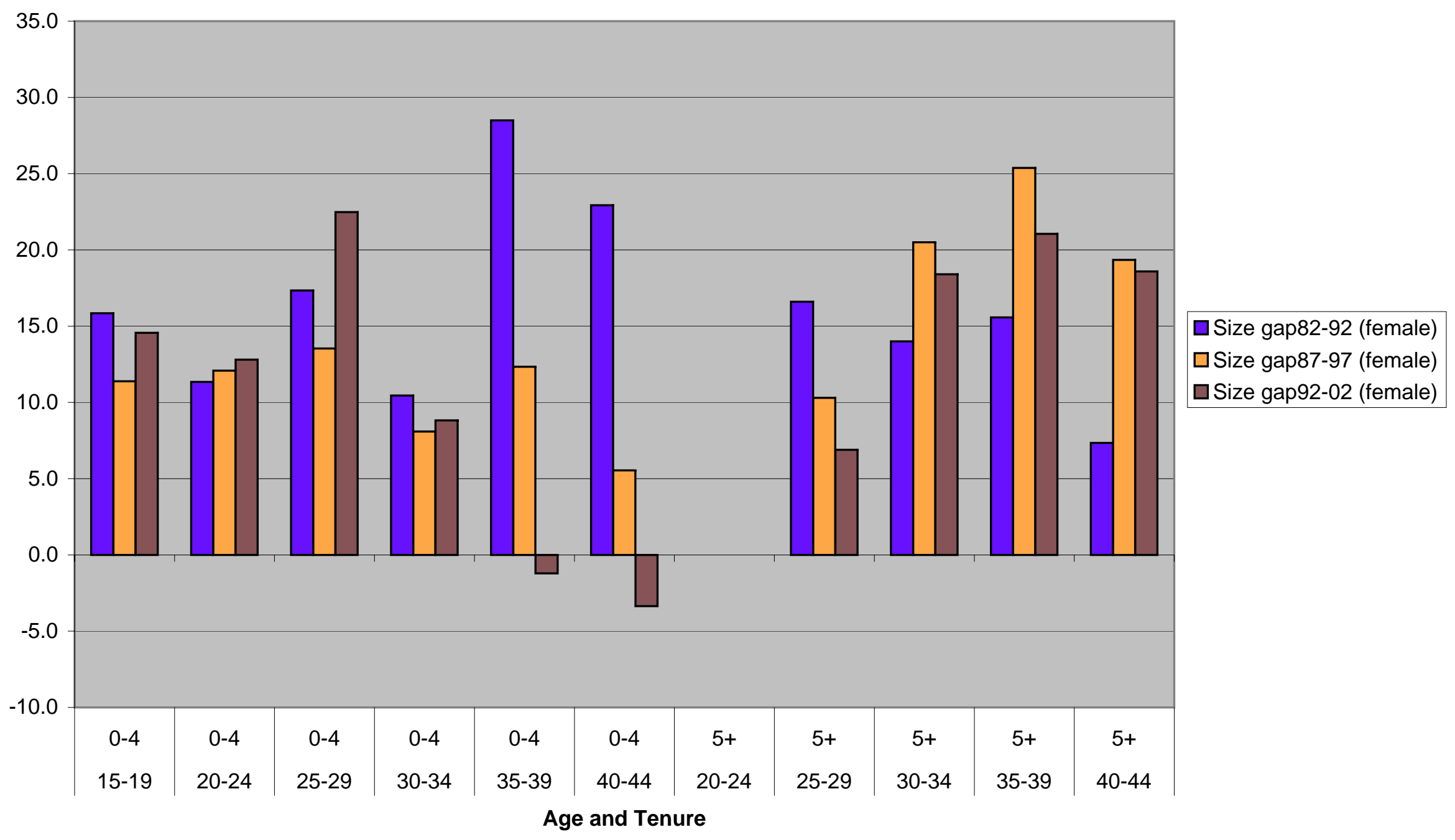


Figure 4 "Lifetime Employment" Cohort as \% of Total Employment in the Same Age Cohort from 1967 to 2002: New College Graduate Hires (Male)

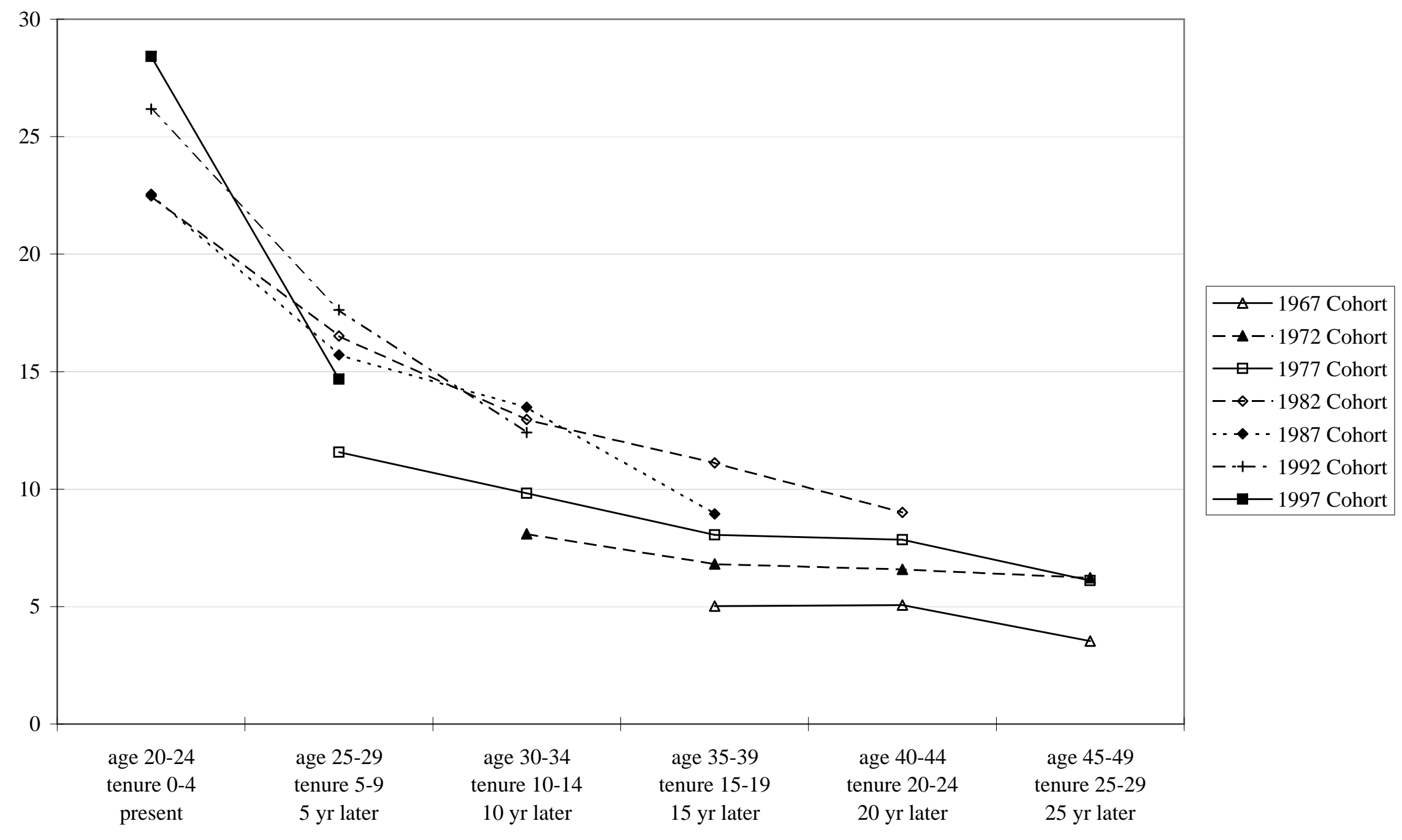


Figure 5 "Lifetime Employment" Cohort as \% of Total Employment in the Same Age Cohort from 1967 to 2002: New Higl School Graduate Hires (Male)

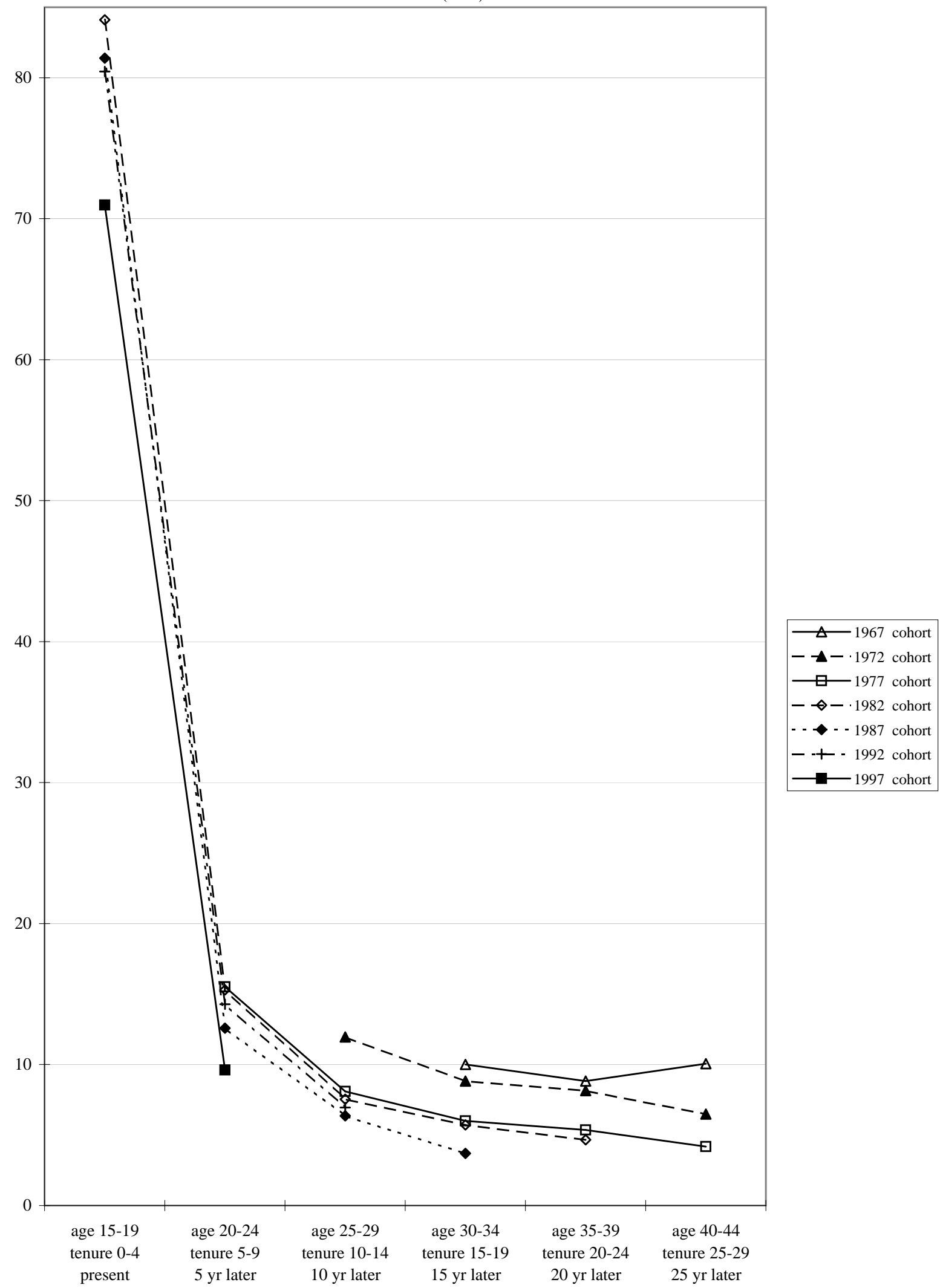


Figure 6: "Lifetime Employment" Cohort as \% of Total Employment in the Same Age Cohort from 1967 to 2002: New College Graduate Hires (Female)

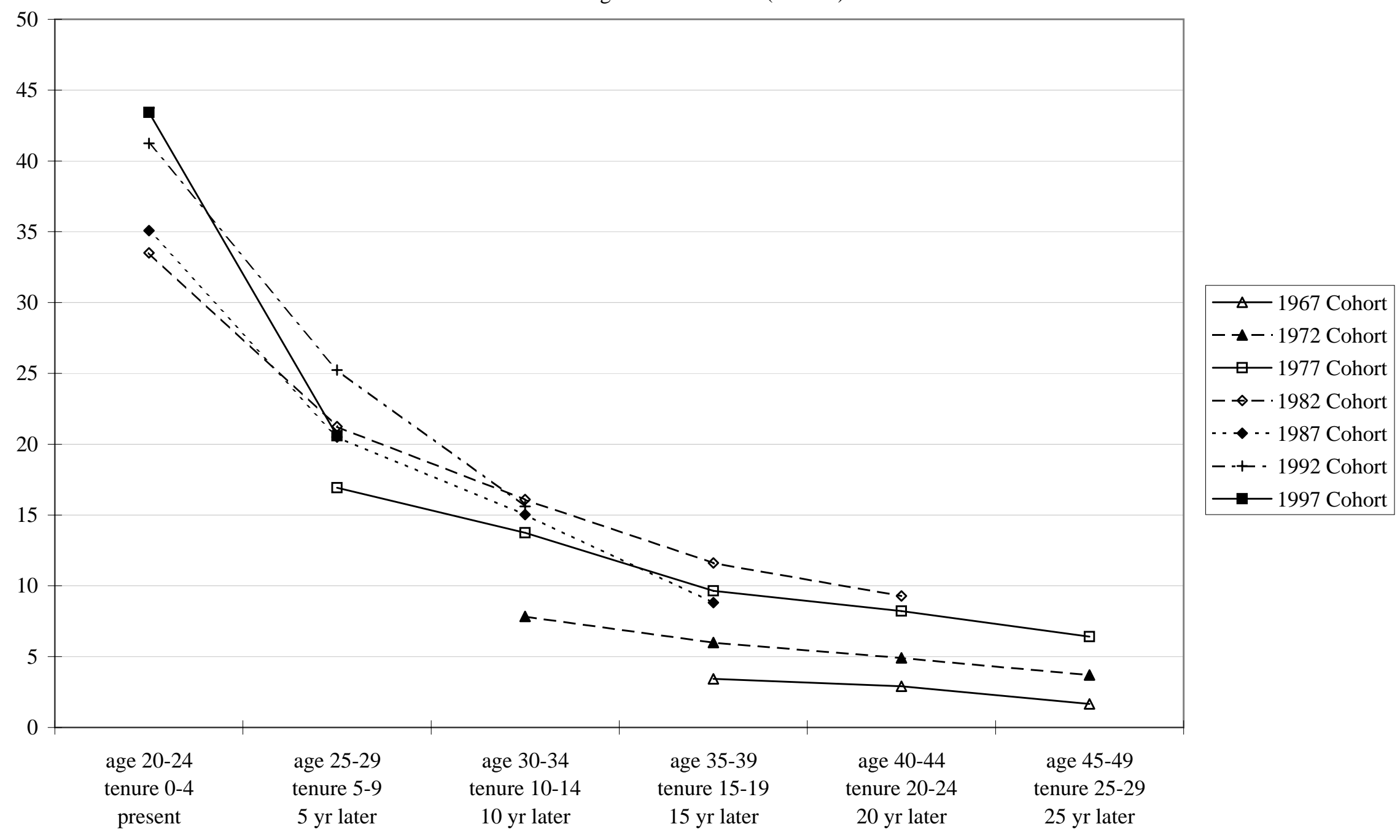


Figure 7 "Lifetime Employment" Cohort as \% of Total Employment in the Same Age Cohort from 1967 to 2002: New Higl School Graduate Hires (Female)

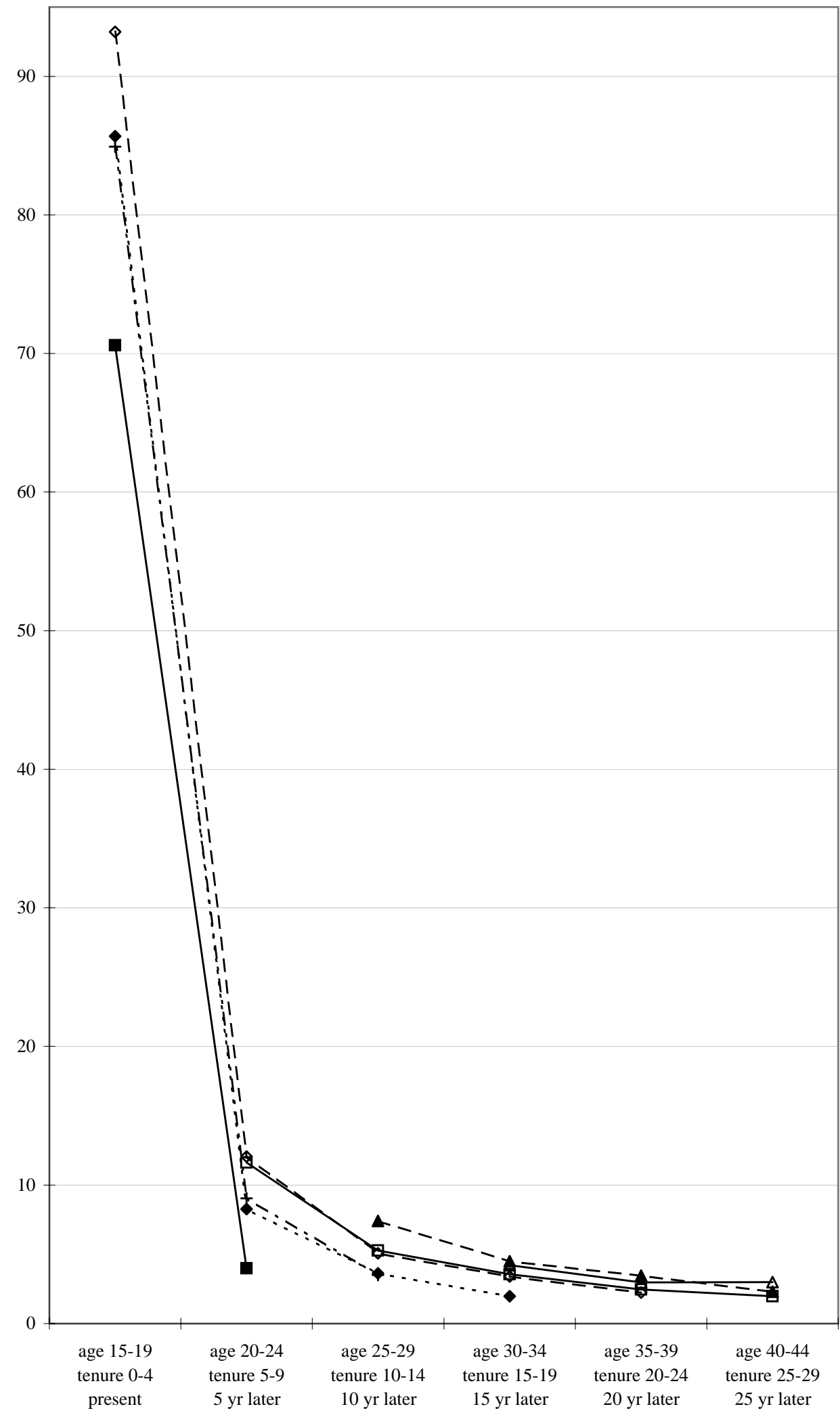


Figure 8 Percent Non-standard Employess over 1982-2002

All, Male and Female

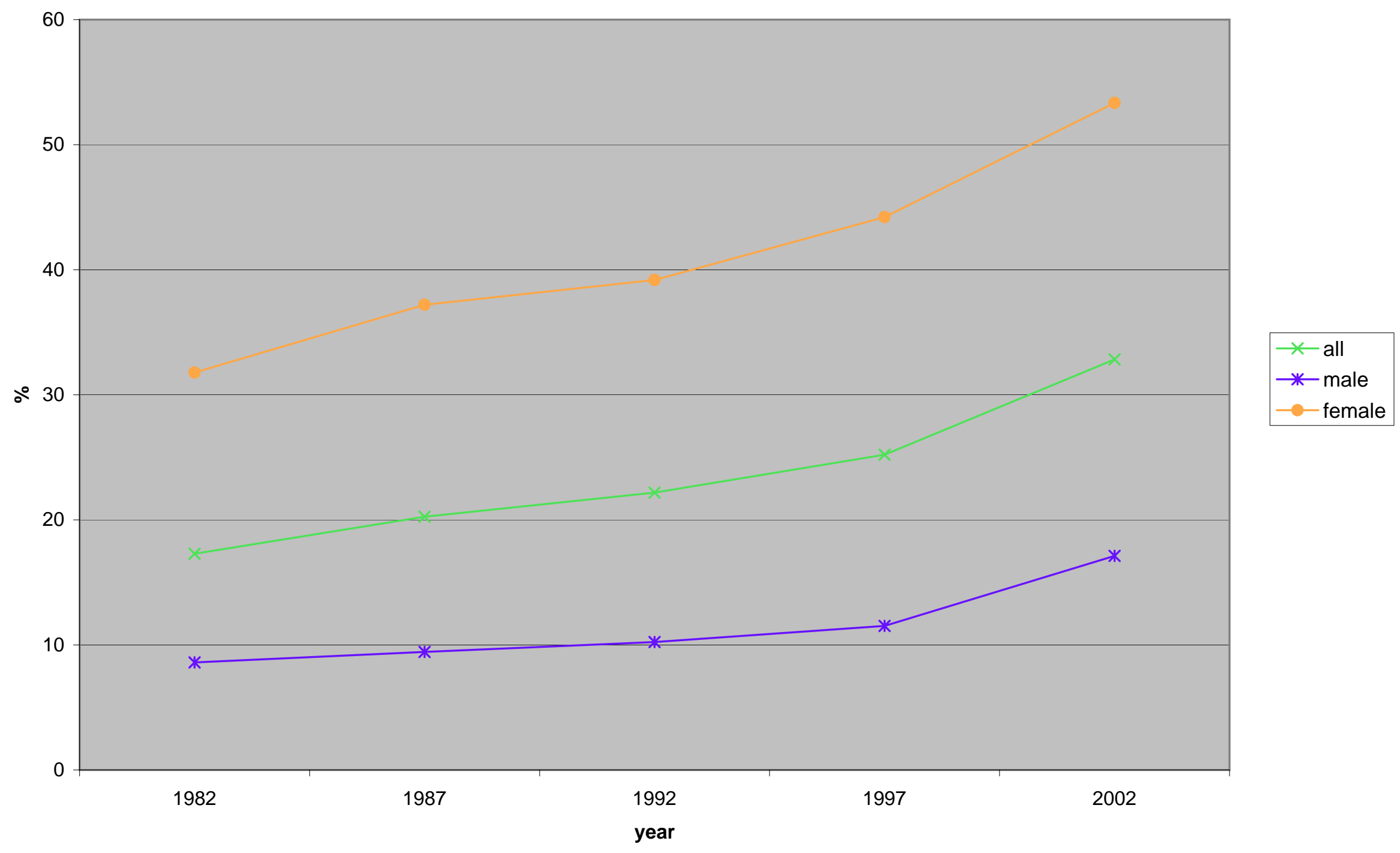


Figure 9 Percent Non-standard Employees over 1982-2002:

College Graduates and High School Graduates

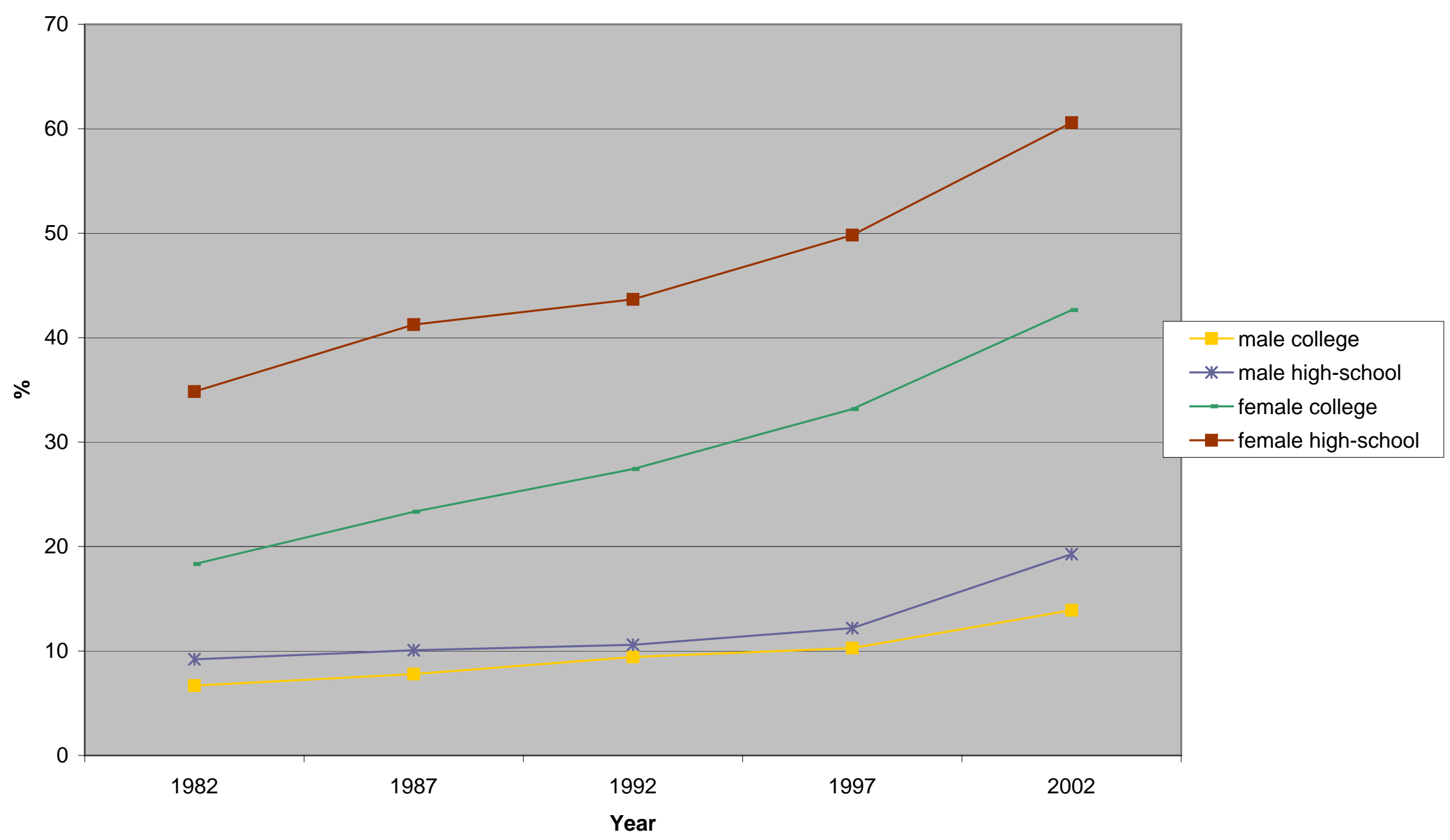


Figure 10 Percent Non-standard Employees over 1982-2002:

Firm Size

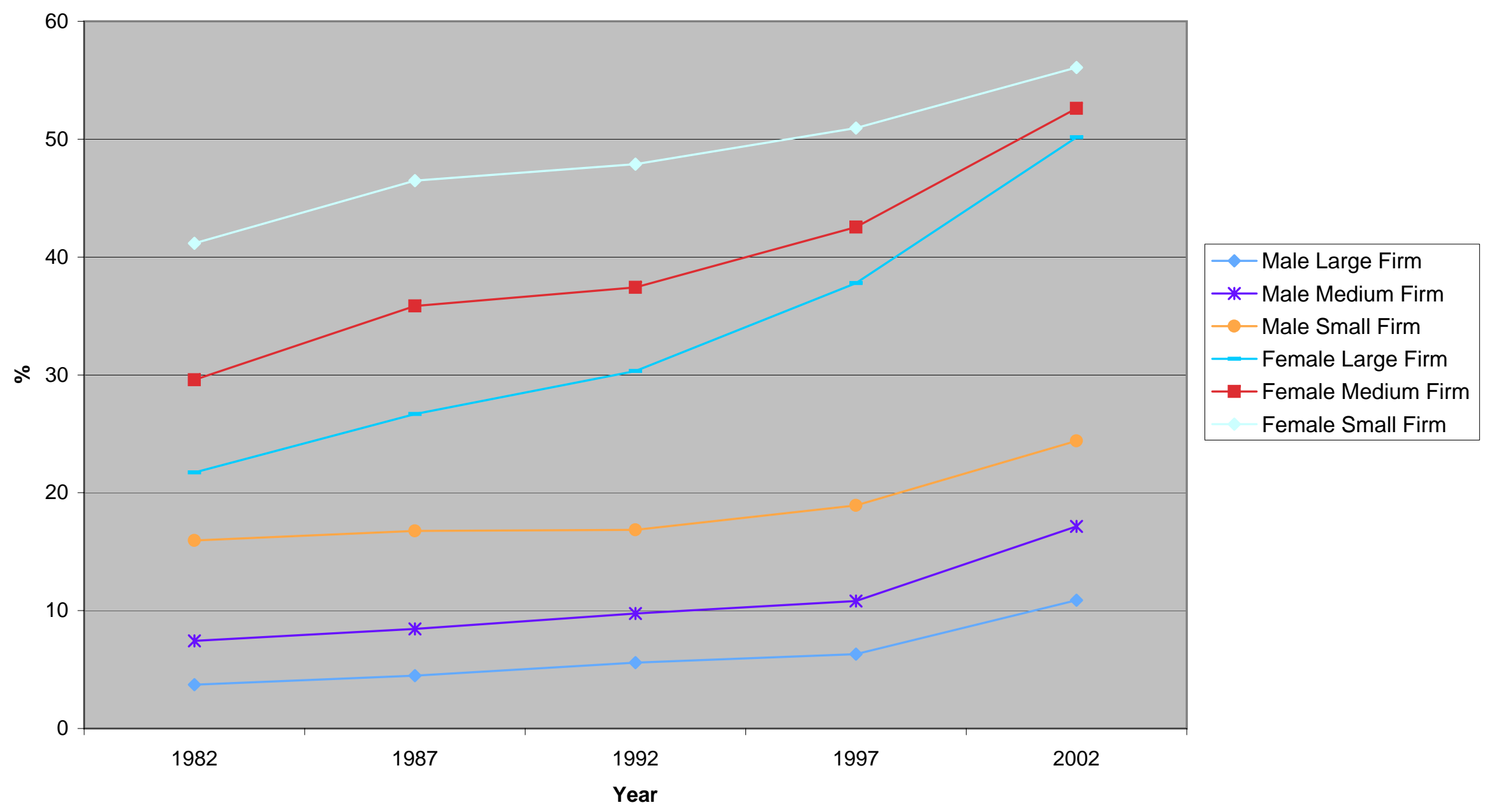


Figure 11 Changes in percent Establishments with JLMCs in 1988, 1994, 1999 and 2004

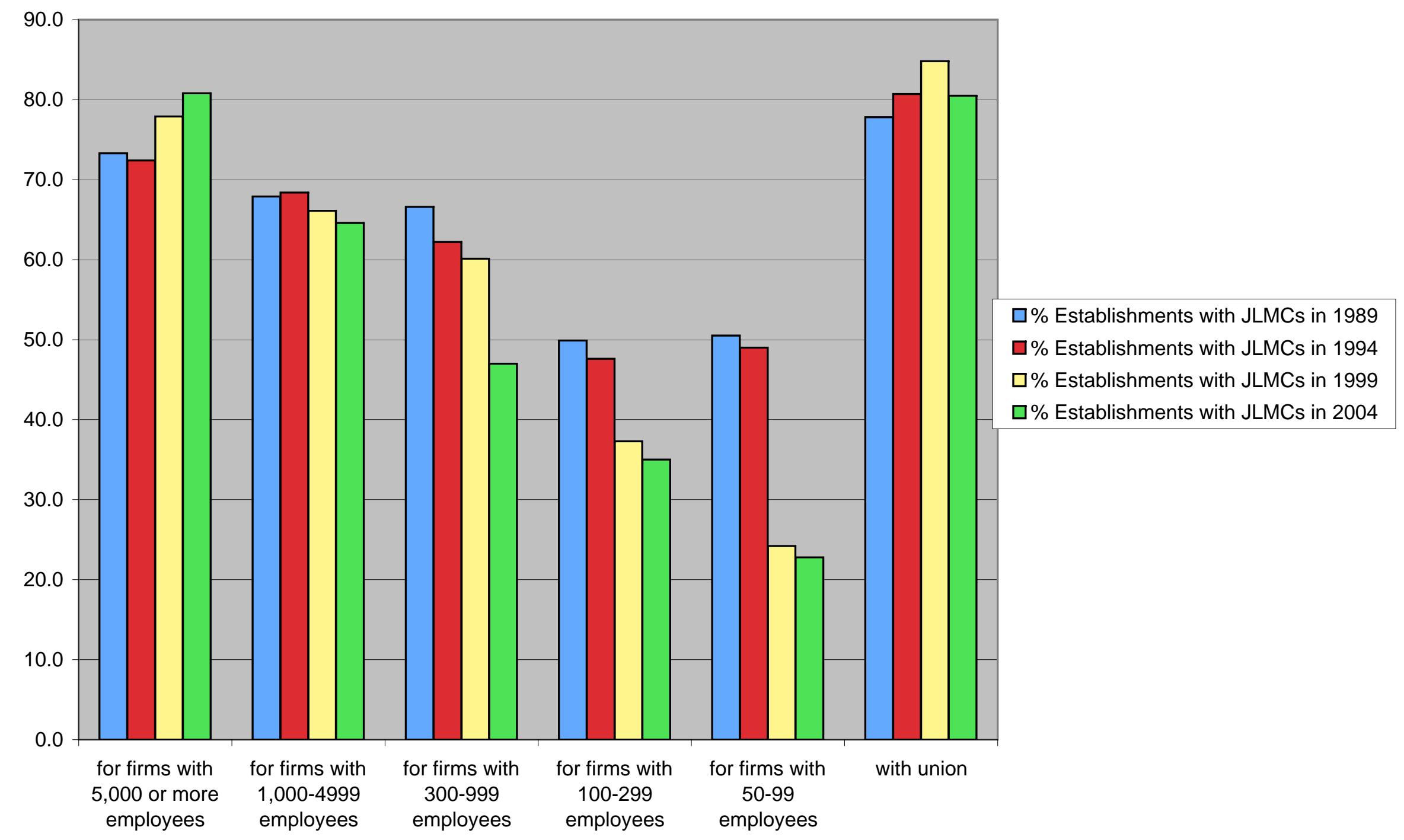


Figure 12 Japanese ESOPs from 1989-2006: TSE-listed Firms

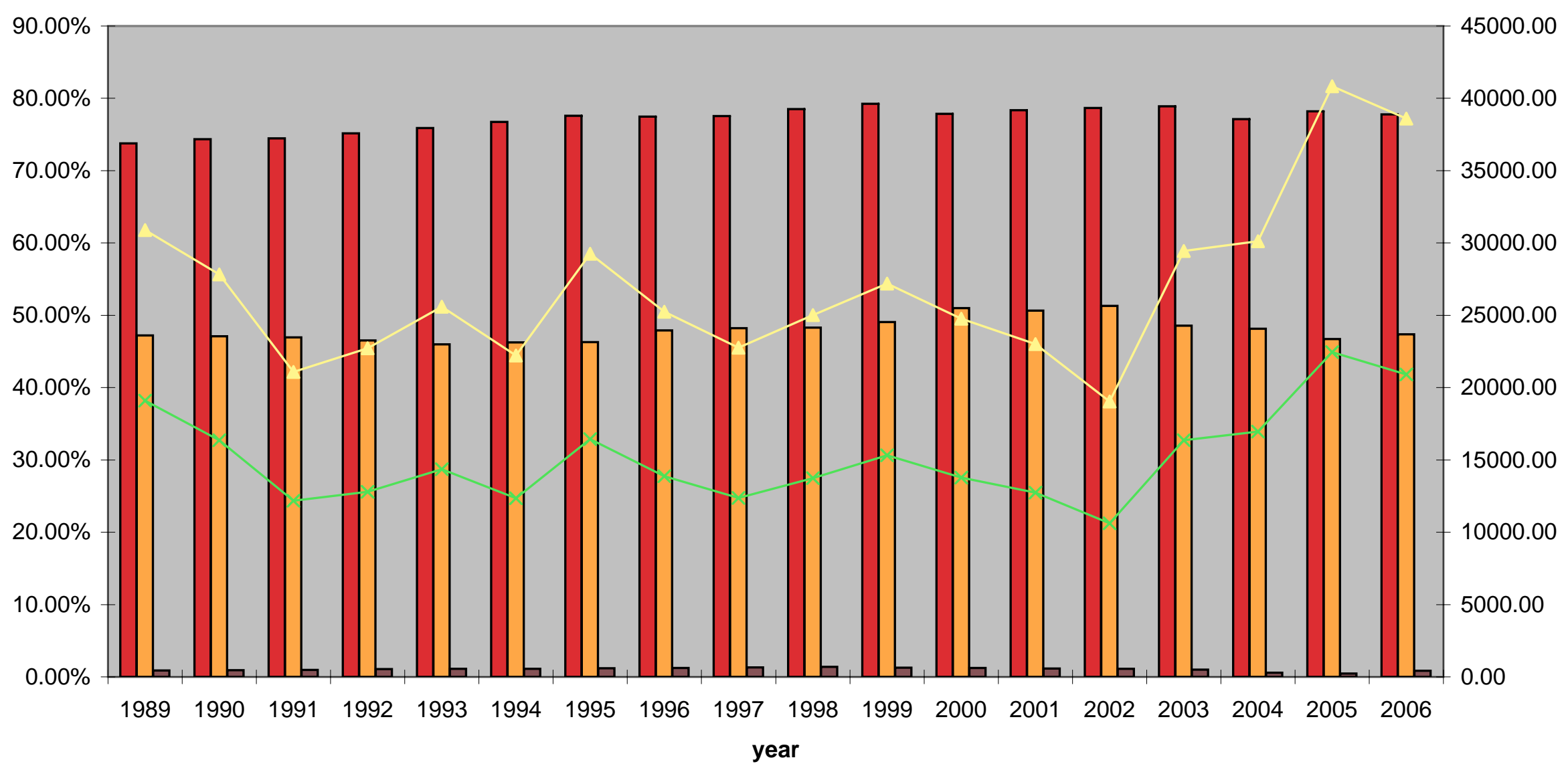

\begin{tabular}{l}
\hline proportion of firms with ESOPs (in percent) \\
ESOP participation rate (in percent) \\
proportion of shares owned by ESOPs (in percent) \\
- market value of outstanding shares owned by ESOPs (in 2005 ten million yen) \\
- market value of outstanding shares owned by ESOPs per participant (in 2005 hundred yen)
\end{tabular}


Figure 13 Participants Who Decreased and Increased Contributions: JFIRM

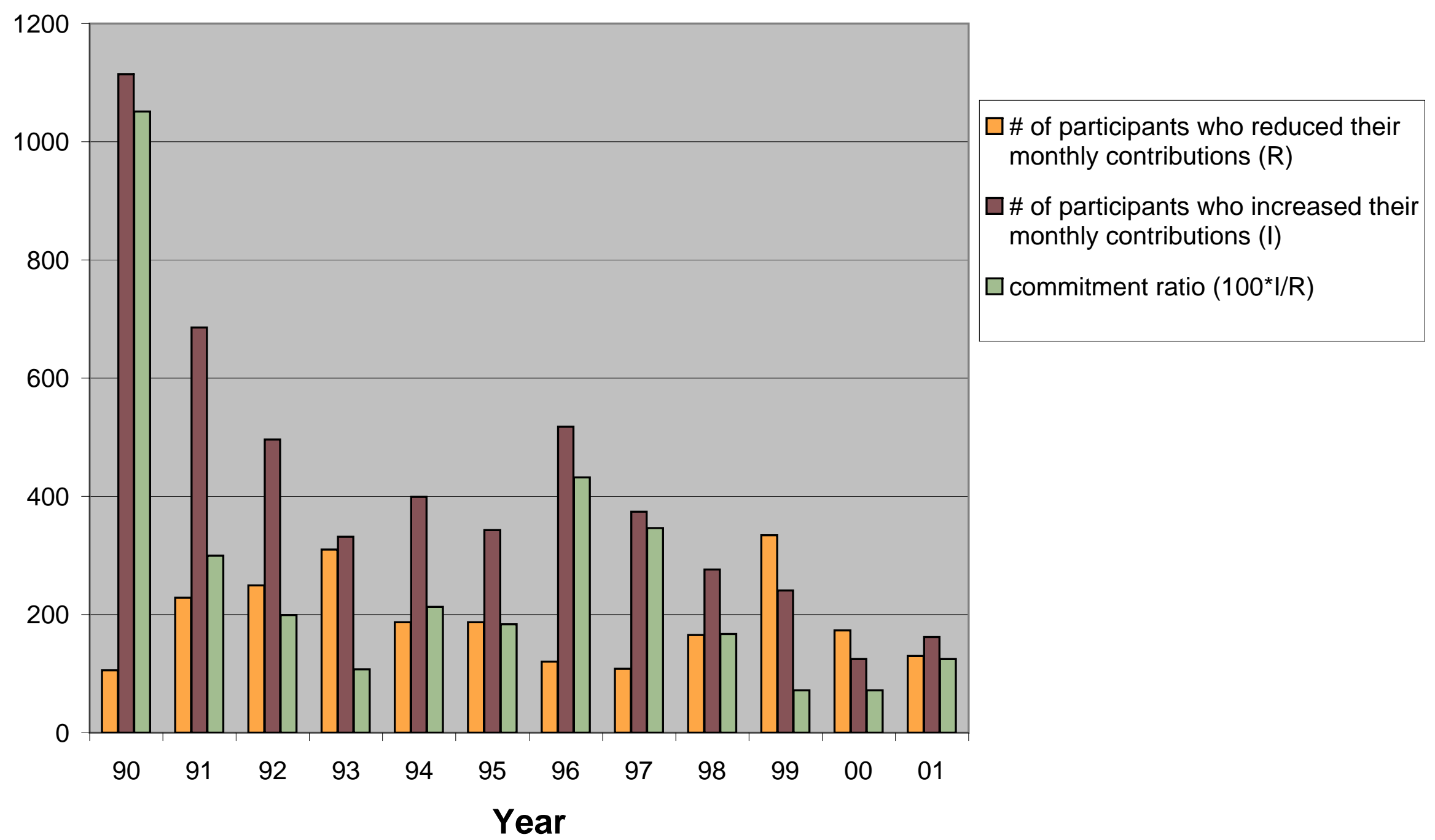


Figure 14 Changes in New Participants: JFIRM

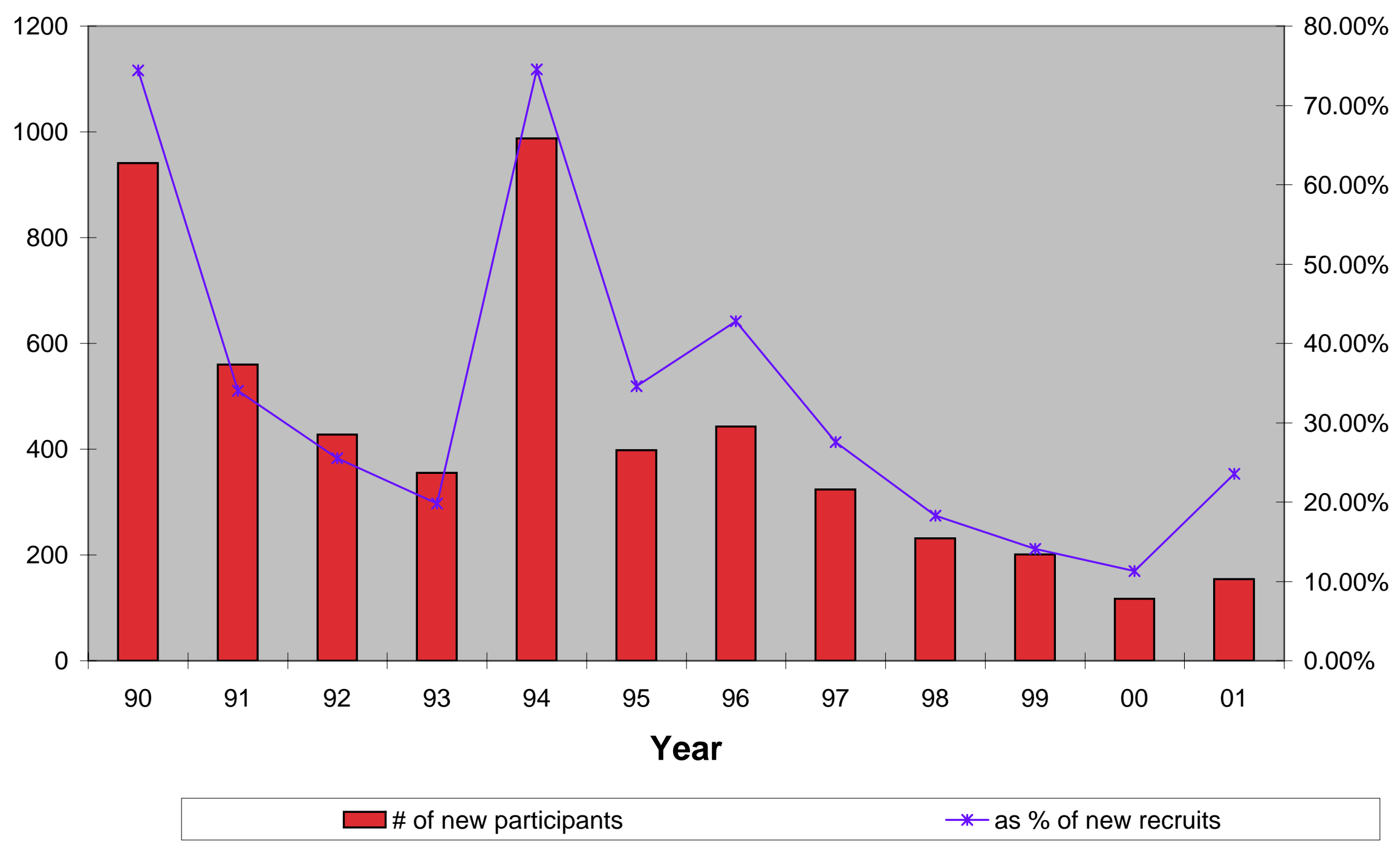




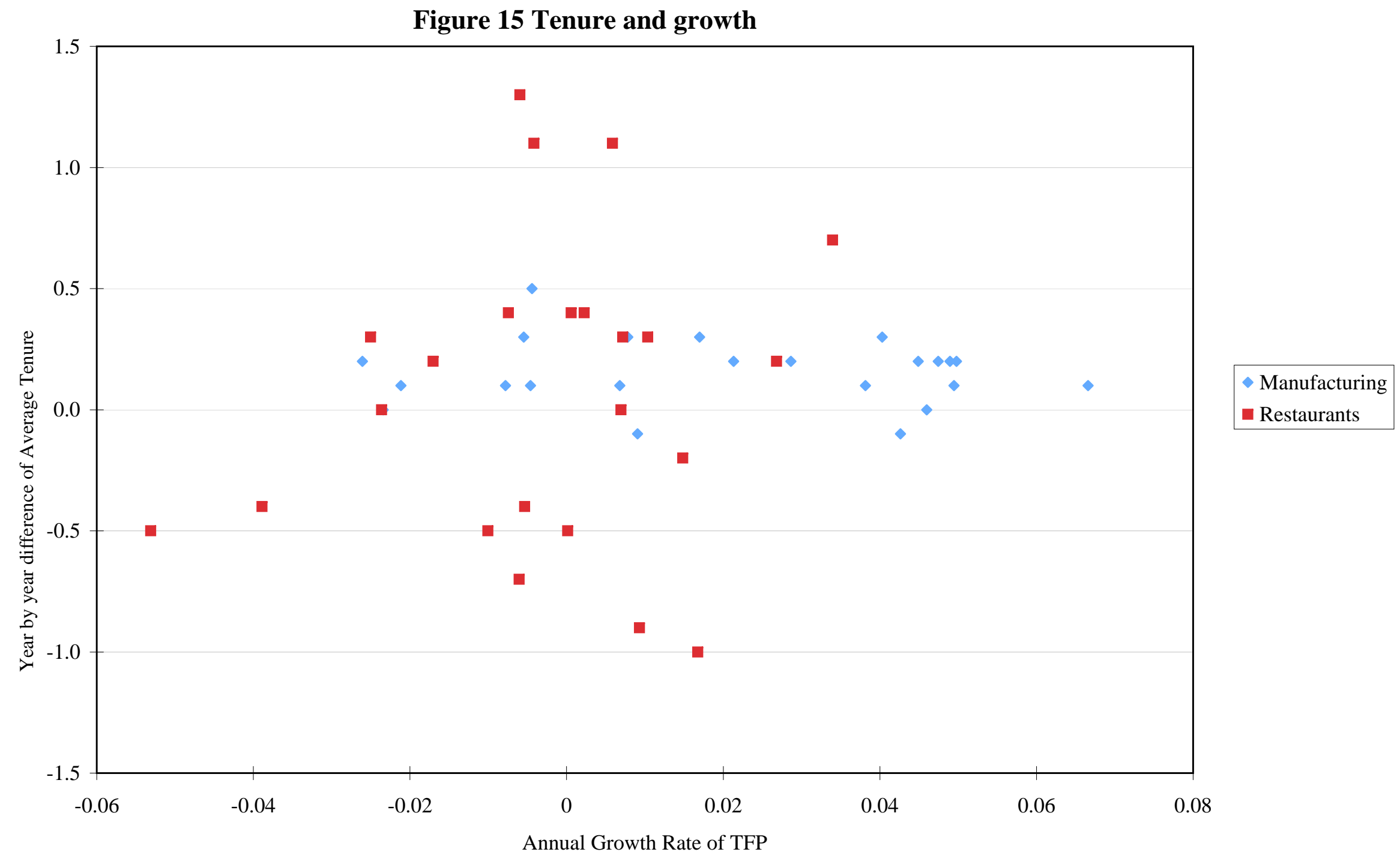

